\title{
Achieving the enhanced photocatalytic degradation of ceftriaxone sodium using CdS-g-C3N4 nanocomposite under visible light irradiation: RSM modeling and optimization
}

Naime AttariKhasraghi

Islamic Azad University

Karim Zare

Islamic Azad University

Ali Mehrizad ( $\square$ ali.mehrizad@yahoo.com )

Islamic Azad University https://orcid.org/0000-0002-9120-0344

Nasser Modirshahla

Islamic Azad University

Mohammad Ali Behnajady

Islamic Azad University

\section{Research Article}

Keywords: Photodegradation, CdS, g-C3N4, Ceftriaxone, RSM, Visible light

Posted Date: February 12th, 2021

DOI: https://doi.org/10.21203/rs.3.rs-212164/v1

License: (c) (1) This work is licensed under a Creative Commons Attribution 4.0 International License.

Read Full License

Version of Record: A version of this preprint was published at Journal of Inorganic and Organometallic Polymers and Materials on March 21st, 2021. See the published version at https://doi.org/10.1007/s10904-021-01967-6. 


\title{
Achieving the enhanced photocatalytic degradation of ceftriaxone sodium using CdS-g-
}

\section{$\mathrm{C}_{3} \mathrm{~N}_{4}$ nanocomposite under visible light irradiation: $\mathrm{RSM}$ modeling and optimization}

\begin{abstract}
In this research, the cadmium sulfide - graphite carbon nitride $\left(\mathrm{CdS}-\mathrm{g}-\mathrm{C}_{3} \mathrm{~N}_{4}\right)$ nanocomposite was synthesized and characterized by X-ray diffraction (XRD), Field emission scanning electron microscopy (FESEM), energy-dispersive X-ray spectrometer (EDX), and transmission electron microscopy (TEM) techniques. The photocatalytic activity of asprepared nanocomposite was evaluated in the degradation of ceftriaxone sodium (CTX) antibiotic from aqueous solution under visible light irradiation. The influence of the operational variables such as the amount of photocatalyst $(\mathrm{g} / \mathrm{L})$, initial CTX concentration $(\mathrm{mg} / \mathrm{L}), \mathrm{pH}$, and irradiation time $(\mathrm{min})$ on the photodegradation process was investigated and optimized using response surface methodology (RSM) - central composite design (CCD) model. The maximum degradation percentage $(92.55 \%)$ was obtained in the optimal condition, including $0.06 \mathrm{~g} / \mathrm{L}$ of CdS-g- $\mathrm{C}_{3} \mathrm{~N}_{4}$ photocatalyst, $15 \mathrm{mg} / \mathrm{L}$ of $\mathrm{CTX}, \mathrm{pH}=10.5$, and irradiation time $=81$ min. The efficient photocatalytic performance of $\mathrm{CdS}-\mathrm{g}-\mathrm{C}_{3} \mathrm{~N}_{4}$ nanocomposite is due to the appropriate alignment of energy levels between the CdS and g$\mathrm{C}_{3} \mathrm{~N}_{4}$, which synergistically impact the charge separation and the degradation efficiency of CTX. The kinetics of the photocatalytic degradation process was well described by Langmuir-Hinshelwood's pseudo-first-order model $\left(\mathrm{kapp}_{\mathrm{ap}}=0.0336 \mathrm{~min}^{-1}\right)$.
\end{abstract}

Keywords: Photodegradation, $\mathrm{CdS}, \mathrm{g}-\mathrm{C}_{3} \mathrm{~N}_{4}$, Ceftriaxone, RSM, Visible light. 


\section{Introduction}

In recent years, the removal of pharmaceutical compounds from wastewaters has attracted a lot of attention due to their various adverse effects on the environment and human life [1-4]. Medicines, especially antibiotics, accumulate over time due to their high solubility in water and long half-life. Therefore, the mutation of microorganisms will occur, causing the antibiotic-resistant genes, which have dangerous consequences [5-7]. Ceftriaxone (CTX) is a beta-lactam cephalosporin antibiotic having 2-(2-amino-1,3-thiazol-4-yl)-2-(methoxyimino) acetylamino and [(2-methyl-5,6-dioxo-1,2,5,6-tetrahydro-1,2,4-triazin-3-yl)sulfanyl]methyl side-groups that is extensively used to treat various bacterial diseases causes by a wide range of gram-positive and gram-negative bacteria [8,9]. Ceftriaxone plays an essential role in environmental pollution due to its high use in medicine and veterinary medicine, and may cause bacterial drug resistance, even in low concentrations [10, 11]. Therefore, the purification of the effluents containing ceftriaxone with appropriate, cost-effective, and highefficiency methods is a challenging issue that researchers have focused on in recent years.

Several procedures can be used to remove antibiotics from water sources [12-15]. Photocatalytic degradation is one of the advanced oxidation processes (AOPs) in which pollutants are destroyed in light radiation and a semiconductor as photocatalyst [16-18]. A suitable photocatalyst should have low band gap energy, high surface area, and good stability [19]. Several inorganic materials (oxides and sulfides) such as $\mathrm{TiO}_{2}, \mathrm{ZnO}, \mathrm{WO}_{3}, \mathrm{Fe}_{2} \mathrm{O}_{3}$, $\mathrm{BiVO}_{4}, \mathrm{CdS}$, and $\mathrm{ZnS}$ have been developed as semiconductors in photocatalytic removal of antibiotics [20-23]. CdS with a suitable band gap (2.42 eV, visible region), low toxicity, and good thermal and chemical stability is an appropriate candidate for photo-assisted degradation purposes [24-26]. There are a lot of researches about CdS nanostructures used as the photocatalyst in wastewater treatments [27-29]. The application of $\mathrm{CdS}$ as a photocatalyst 
has been limited because of the high recombination of charge carriers (electrons and holes) and low optical stability against light irradiation [30].

Recently, the combination of inorganic metal sulfides with carbon-based materials has been considered a practical approach to overcoming the problem [31]. In this case, the advantages of both organic and inorganic semiconductors improved photocatalytic efficiency due to the fast charge separation and transfer. Among different carbon allotropies, graphitic carbon nitride $\left(\mathrm{g}-\mathrm{C}_{3} \mathrm{~N}_{4}\right)$ has been attracted lots of attention owing to optoelectrical and chemical properties [32-34]. Chen et al. [35] reported the carboxylic acid - functionalized $\mathrm{CdS} / \mathrm{g}-\mathrm{C}_{3} \mathrm{~N}_{4}$ heterojunction as an efficient photocatalyst for sulfamethazine decomposition. The $\mathrm{CdS} /$ spherical $\mathrm{g}-\mathrm{C}_{3} \mathrm{~N}_{4}$ photocatalyst was prepared by $\mathrm{Wu}$ and Wang et al. [36] using the solvothermal method, which showed $93.2 \%$ tetracycline degradation. Li et al. [37] demonstrated that the $\mathrm{Fe}_{3} \mathrm{O}_{4} / \mathrm{CdS} / \mathrm{g}-\mathrm{C}_{3} \mathrm{~N}_{4}$ photocatalyst had excellent efficiency in the decomposing of the ciprofloxacin under visible light.

Generally, obtaining the optimal conditions for operational parameters in the photocatalytic degradation of pollutants requires several experiments, which are very time consuming and costly. Also in this case, the effect of each variable is discussed independently, while other variables are considered constant and the interaction between the parameters cannot be examined. To overcome the mentioned limitations, the response surface methodology (RSM) method was used for optimizing the photodegradation process. Using RSM as the appropriate mathematical and statistical method, it is possible to provide a model that correlates the various experimental variables (such as the initial concentration of pollutant, $\mathrm{pH}$, irradiation time, the amount of photocatalyst) and the response (photodegradation percentage) obtained by performing fewer tests with greater accuracy. In the RSM category, central composite design (CCD) has been widely used for the optimization of the photocatalytic degradation 
process because of the advantage of optimizing multifactor problems with the optimum number of experimental runs [3].

In this project, the $\mathrm{CdS}-\mathrm{g}-\mathrm{C}_{3} \mathrm{~N}_{4}$ nanocomposite was synthesized via the chemical precipitation method and applied as an efficient photocatalyst for the decomposition of ceftriaxone (CTX) under visible light irradiation. The degradation process was investigated by the experimental design using RSM based on CCD and the optimal condition obtained considering the interaction and individual effects of input variables (amount of photocatalyst, ceftriaxone concentration, $\mathrm{pH}$, and irradiation time) and their primary influence over time. The process was also examined from a kinetic point of view.

\section{Materials and methods}

\subsection{Synthesis of $\mathrm{g}-\mathrm{C}_{3} \mathrm{~N}_{4}$ powder}

The synthesis of $\mathrm{g}-\mathrm{C}_{3} \mathrm{~N}_{4}$ powder was carried out using a calcination process. $5 \mathrm{~g}$ melamine $\left(\mathrm{C}_{3} \mathrm{H}_{6} \mathrm{~N}_{6}\right.$, Merck) was put into a semi-closed crucible and heated in a muffle furnace at $520{ }^{\circ} \mathrm{C}$ for $4 \mathrm{~h}$. The prepared yellow powder of $\mathrm{g}-\mathrm{C}_{3} \mathrm{~N}_{4}$ was collected and grinned.

\subsection{Synthesis of $\mathrm{CdS}-\mathrm{g}-\mathrm{C}_{3} \mathrm{~N}_{4}$ nanocomposite}

First, 0.0772 gr of as-prepared $\mathrm{g}-\mathrm{C}_{3} \mathrm{~N}_{4}$ powder was dispersed in $50 \mathrm{ml}$ distilled water in the ultrasonic bath for $15 \mathrm{~min}$. Then, $50 \mathrm{ml}$ cadmium chloride monohydrate $\left(\mathrm{CdCl}_{2} . \mathrm{H}_{2} \mathrm{O}, \mathrm{Merck}\right)$ aqueous solution $(0.1 \mathrm{M})$ and $20 \mathrm{ml}$ methanol $\left(\mathrm{CH}_{3} \mathrm{OH}\right.$, Merck) were added, followed by sonication for $30 \mathrm{~min}$. After that, a $50 \mathrm{ml}$ solution of sodium sulfide ( $\mathrm{Na} 2 \mathrm{~S}$, Merck) $0.1 \mathrm{M}$ was added gradually into the mixture and stirred for $1 \mathrm{~h}$. The obtained precipitate was centrifuged and was washed several times with ethanol and distilled water. Finally, the asprepared nanocomposite was dried at $80{ }^{\circ} \mathrm{C}$ in the oven for $2 \mathrm{~h}$ and heated in a furnace at 500 ${ }^{\circ} \mathrm{C}$ for $1 \mathrm{~h}$.

\subsection{Characterization}


The crystallographic structures of pure $\mathrm{CdS}$, pure $\mathrm{g}-\mathrm{C}_{3} \mathrm{~N}_{4}$, and as-synthesized $\mathrm{CdS}-\mathrm{g}-\mathrm{C}_{3} \mathrm{~N}_{4}$ nanocomposite were evaluated by X-ray diffraction (XRD) analysis using PHILIPS (PW1730, Nederland) with $\mathrm{Cu}-\mathrm{k} \alpha$ radiation $\left(\lambda=1.54 \mathrm{~A}^{\circ}, 40 \mathrm{kV}, 30 \mathrm{~mA}\right)$. The Field emission scanning electron microscopy (FESEM) (TESCAN, MIRA III) was used for evaluating the morphology of compounds. The elemental composition was determined using an energy dispersive X-ray spectrometer (EDX) (TESCAN, MIRA III equipped with SAMX detector). The transmission electron microscopy (TEM) was done by LEO $906 \mathrm{E}(100 \mathrm{kV})$.

\subsection{Investigation of photocatalytic activity}

The photocatalytic performance of $\mathrm{CdS}-\mathrm{g}-\mathrm{C}_{3} \mathrm{~N}_{4}$ nanocomposite was evaluated by the degradation of ceftriaxone antibiotic under visible light irradiation. All the experiments were performed in a photo reactor equipped with a LED-300 W (OSRAM, Germany) as the light source and a glass optical filter for cut off the components with $\lambda>420 \mathrm{~nm}$.

The CdS-g- $\mathrm{C}_{3} \mathrm{~N}_{4}$ nanocomposites with different $\mathrm{g}-\mathrm{C}_{3} \mathrm{~N}_{4}$ content $(0.00772,0.0361,0.0772$, 0.1805 , and 0.361 gr) were synthesized and their photocatalytic performances in the degradation of CTX were evaluated. The CdS-g- $\mathrm{C}_{3} \mathrm{~N}_{4}$ nanocomposite containing 0.0772 gr g$\mathrm{C}_{3} \mathrm{~N}_{4}$ showed the maximum efficiency for CTX decomposition and selected for the RSM experiment. Before performing each experiment (each run) designed by RSM, the suspensions were magnetically stirred in the dark for $60 \mathrm{~min}$ to obtain absorption/desorption equilibrium.

In each test, $100 \mathrm{ml}$ of ceftriaxone solution with appropriate initial concentration and $\mathrm{pH}$ along with a certain amount of photocatalyst powder was stirred $(250 \mathrm{rpm})$. The $\mathrm{HCl}$ and $\mathrm{NaOH}$ solutions $(0.1 \mathrm{M})$ were used for adjusting the $\mathrm{pH}$.

After a specific time, $5 \mathrm{ml}$ of the solution was sampled and centrifuged. The absorbance of ceftriaxone solution was determined by the single-beam UV-Vis spectrophotometer 
(Shimadzu UV- Mini-1240) at the $\lambda_{\max }=240 \mathrm{~nm}$. The percentage of ceftriaxone degradation was calculated by Eq. 1 .

Degradation $\quad(\%) \quad=\quad\left(\frac{\mathrm{C}_{0}-\mathrm{C}_{\mathrm{t}}}{\mathrm{C}_{0}}\right) \quad \times \quad 100$

where $\mathrm{C}_{0}$ and $\mathrm{C}_{\mathrm{t}}$ are the ceftriaxone concentrations $(\mathrm{mg} / \mathrm{L})$ at initial time $(\mathrm{t}=0)$ and after a certain irradiation time $(\mathrm{t})$, respectively.

\subsection{Experimental design}

The photocatalytic analysis was performed according to the experiments designed by DesignExpert@11 software using central composite design (CCD) based on response surface methodology (RSM).

In this regard, four variables (amount of $\mathrm{CdS}-\mathrm{g}-\mathrm{C}_{3} \mathrm{~N}_{4}$ photocatalyst (g/L), initial concentration of ceftriaxone $(\mathrm{mg} / \mathrm{L}), \mathrm{pH}$, and irradiation time $(\mathrm{min}))$ in five levels were chosen according to Table 1 .

Table 1. Levels of the operational parameters.

\begin{tabular}{cccccc}
\hline variables & \multicolumn{5}{c}{ levels } \\
\hline $\mathrm{A}:\left[\mathrm{CdS}-\mathrm{g}-\mathrm{C}_{3} \mathrm{~N}_{4}\right](\mathrm{g} / \mathrm{L})$ & 0.01 & 0.03 & 0.05 & 0.07 & 0.09 \\
\hline $\mathrm{B}:[\mathrm{CTX}](\mathrm{mg} / \mathrm{L})$ & 5 & 10 & 15 & 20 & 25 \\
\hline $\mathrm{C}: \mathrm{pH}$ & 3 & 5 & 7 & 9 & 11 \\
\hline D: Time $(\min )$ & 20 & 45 & 70 & 95 & 120 \\
\hline
\end{tabular}

The 30 experiments (30 runs) were designed and performed based on operational variables. The designed experiments, along with the actual and predicted results, were presented in Table 2. To evaluate the effect of each variable, a quadratic polynomial model was proposed as a function of independent variables (operational variables) and measured response (degradation percentage) with the general equation as follows (Eq. 2) [38]:

$\mathrm{y}=\beta_{0}+\sum_{\mathrm{i}=1}^{\mathrm{k}} \beta_{\mathrm{i}} \mathrm{X}_{\mathrm{i}}+\sum_{\mathrm{i}=1}^{\mathrm{k}} \beta_{\mathrm{ii}} \mathrm{X}_{\mathrm{i}}^{2}+\sum_{\mathrm{i}=1}^{\mathrm{k}} \sum_{\mathrm{j}=1}^{\mathrm{k}} \beta_{\mathrm{ij}} \mathrm{X}_{\mathrm{i}} \mathrm{X}_{\mathrm{j}}+\varepsilon$ 
where $\mathrm{y}$ is the predicted degradation percentage (\%), $\beta_{0}$ is the constant, $\beta_{\mathrm{i}}, \beta_{\mathrm{ii}}$, and $\beta_{\mathrm{ij}}$ are the linear, quadratic, and mutual coefficients, respectively. $\mathrm{X}_{\mathrm{i}}$ and $\mathrm{X}_{\mathrm{j}}$ are the operational variables. $\mathrm{X}_{\mathrm{i}}^{2}$ and $\mathrm{X}_{\mathrm{i}} \mathrm{X}_{\mathrm{j}}$ show the quadratic and mutual effects of operational variables, respectively. $\varepsilon$ is the residual value related to the experiments [38]. Analysis of Variance (ANOVA), p- value, and F- value were used for statistical analysis of the results.

Table 2. Designed experiments along with the actual and predicted results.

\begin{tabular}{|c|c|c|c|c|c|c|c|}
\hline \multirow[b]{2}{*}{ Std. } & \multirow{2}{*}{ Run } & \multirow{2}{*}{$\begin{array}{c}A:\left[\mathrm{CdS}-\mathrm{g}-\mathrm{C}_{3} \mathrm{~N}_{4}\right] \\
(\mathrm{g} / \mathrm{L})\end{array}$} & \multirow{2}{*}{$\begin{array}{c}\text { B: }[\mathrm{CTX}] \\
(\mathrm{mg} / \mathrm{L})\end{array}$} & \multirow{2}{*}{$\mathrm{C}: \mathrm{pH}$} & \multirow{2}{*}{$\begin{array}{l}\text { D: Time } \\
\text { (min) }\end{array}$} & \multicolumn{2}{|c|}{$\mathrm{R}(\%)$} \\
\hline & & & & & & Actual & predicted \\
\hline 2 & 1 & 0.07 & 10 & 5 & 45 & 69.39 & 69.22 \\
\hline 21 & 2 & 0.05 & 15 & 3 & 70 & 72.89 & 72.79 \\
\hline 1 & 3 & 0.03 & 10 & 5 & 45 & 64.64 & 65.10 \\
\hline 23 & 4 & 0.05 & 15 & 7 & 20 & 61.32 & 60.92 \\
\hline 19 & 5 & 0.05 & 5 & 7 & 70 & 65.81 & 66.20 \\
\hline 16 & 6 & 0.07 & 20 & 9 & 95 & 85.19 & 85.21 \\
\hline 8 & 7 & 0.07 & 20 & 9 & 45 & 66.15 & 65.52 \\
\hline 11 & 8 & 0.03 & 20 & 5 & 95 & 67.29 & 67.16 \\
\hline 26 & 9 & 0.05 & 15 & 7 & 70 & 68.06 & 67.64 \\
\hline 7 & 10 & 0.03 & 20 & 9 & 45 & 54.46 & 55.21 \\
\hline 22 & 11 & 0.05 & 15 & 11 & 70 & 86.46 & 87.02 \\
\hline 18 & 12 & 0.09 & 15 & 7 & 70 & 66.19 & 65.95 \\
\hline 24 & 13 & 0.05 & 15 & 7 & 120 & 79.39 & 80.25 \\
\hline 29 & 14 & 0.05 & 15 & 7 & 70 & 68.25 & 67.64 \\
\hline 4 & 15 & 0.07 & 20 & 5 & 45 & 66.79 & 67.61 \\
\hline 10 & 16 & 0.07 & 10 & 5 & 95 & 63.41 & 63.15 \\
\hline 28 & 17 & 0.05 & 15 & 7 & 70 & 68.33 & 67.64 \\
\hline 3 & 18 & 0.03 & 20 & 5 & 45 & 66.17 & 65.56 \\
\hline 25 & 19 & 0.05 & 15 & 7 & 70 & 65.11 & 67.64 \\
\hline 17 & 20 & 0.01 & 15 & 7 & 70 & 56.53 & 57.23 \\
\hline 9 & 21 & 0.03 & 10 & 5 & 95 & 65.06 & 64.74 \\
\hline 12 & 22 & 0.07 & 20 & 5 & 95 & 63.55 & 63.50 \\
\hline 27 & 23 & 0.05 & 15 & 7 & 70 & 69.95 & 67.64 \\
\hline 15 & 24 & 0.03 & 20 & 9 & 95 & 81.38 & 80.61 \\
\hline 6 & 25 & 0.07 & 10 & 9 & 45 & 69.38 & 69.70 \\
\hline 30 & 26 & 0.05 & 15 & 7 & 70 & 66.11 & 67.64 \\
\hline 5 & 27 & 0.03 & 10 & 9 & 45 & 58.52 & 57.62 \\
\hline 14 & 28 & 0.07 & 10 & 9 & 95 & 88.05 & 87.72 \\
\hline 13 & 29 & 0.03 & 10 & 9 & 95 & 81.38 & 81.05 \\
\hline
\end{tabular}




\begin{tabular}{llllllll}
20 & 30 & 0.05 & 25 & 7 & 70 & 64.07 & 64.14 \\
\hline
\end{tabular}

\section{Results and discussion}

\subsection{Characterization}

The phase and crystallographic structures of the pure CdS, pristine g- $\mathrm{C}_{3} \mathrm{~N}_{4}$, and CdS-g- $\mathrm{C}_{3} \mathrm{~N}_{4}$ nanocomposite were studied by the XRD analysis (Fig. 1).

$<$ Fig.1>

Fig. 1 (a) illustrates the XRD pattern of the pure CdS. The diffraction peaks at $2 \theta 24.71$, 26.46, 28.16, 36.61, 43.71, 47.86, 51.91, 71.11, and 75.51 are related to (100), (002), (101), (102), (110), (103), (112), (203), and (211) crystal planes of hexagonal wurtzite structure (JCPDS data card No. 41-1049) [39]. Two peaks of $\mathrm{g}-\mathrm{C}_{3} \mathrm{~N}_{4}$ were observed at $2 \theta 13.31^{\circ}(100)$ and $27.42^{\circ}(002)$, which are assigned to tri-s-triazine units and interlayer stacking of the conjugated double bonds, respectively (Fig.1 (b)) [40, 41]. It can be seen that the XRD patterns of pure CdS and CdS-g- $\mathrm{C}_{3} \mathrm{~N}_{4}$ are similar which is in good agreement with the literatures $[42,43]$. It is considered that the intensity of (002) peak in the XRD pattern of the CdS-g- $\mathrm{C}_{3} \mathrm{~N}_{4}$ nanocomposite (Fig. 1 (c)) has increased compared to pure CdS. The relative intensities of diffraction peaks are related to the crystal growth orientation. Therefore, increasing the (002) intensity in the XRD pattern of CdS-g- $\mathrm{C}_{3} \mathrm{~N}_{4}$ nanocomposite is assigned to the growth orientation change of $\mathrm{CdS}$ in the presence of $\mathrm{g}-\mathrm{C}_{3} \mathrm{~N}_{4}$ due to the formation of the close interface and interactions between the $\mathrm{g}-\mathrm{C}_{3} \mathrm{~N}_{4}$ and $\mathrm{CdS}$ [43].

The FE-SEM images, together with EDX results of the compounds, were depicted in Fig.2. According to Fig.2 (a $a_{1}$, the irregular-shaped CdS nanoparticles can be observed with high aggregation due to the high density of particle growth.

From Fig. $2\left(b_{1}\right)$, the pristine ${ }_{-}-\mathrm{C}_{3} \mathrm{~N}_{4}$ has irregular wrinkled sheets with a lamellar structure in which layers are stacked together. In the case of CdS-g- $\mathrm{C}_{3} \mathrm{~N}_{4}$ nanocomposite (Fig. $2\left(\mathrm{c}_{1}\right)$ ), the irregular dispersion of high-density $\mathrm{CdS}$ nanoparticles in the $\mathrm{g}-\mathrm{C}_{3} \mathrm{~N}_{4}$ sheets can be seen, 
which makes appropriate interfacial connections for efficient charge separation and transfer. The presence of corresponding peaks for each compound in EDX spectra declared the formation of them.

$<$ Fig. $2>$

The synthesis of $\mathrm{CdS}-\mathrm{g}-\mathrm{C}_{3} \mathrm{~N}_{4}$ nanocomposite is also characterized by transmission electron microscopy. TEM image of $\mathrm{CdS}-\mathrm{g}-\mathrm{C}_{3} \mathrm{~N}_{4}$ nanocomposite was illustrated in Fig. 3 showing that the CdS nanoparticles distribute irregularly on the $\mathrm{g}-\mathrm{C}_{3} \mathrm{~N}_{4}$ layers.

$<$ Fig.3>

The bang gap energy of synthesized $\mathrm{CdS}-\mathrm{g}-\mathrm{C}_{3} \mathrm{~N}_{4}$ nanocomposite was determined using UVVis spectroscopy. The UV-Vis absorption spectrum of $\mathrm{CdS}-\mathrm{g}-\mathrm{C}_{3} \mathrm{~N}_{4}$ nanocomposite was illustrated in Fig 4.

$<$ Fig.4>

The band gap energy $\left(\mathrm{E}_{\mathrm{g}}\right)$ value are determined from the extrapolating of the linear parts of the $(\mathrm{Ah} v)^{2}$ versus $\mathrm{h} v$ according to $(\mathrm{Ah} v)^{2}=\mathrm{B}\left(\mathrm{h} v-\mathrm{E}_{\mathrm{g}}\right)$ Tauc-Mott's equation where $\mathrm{A}$ is the absorbance (a.u.), hv is the photon energy (eV), B is the proportional constant, $\mathrm{Eg}$ is the band gap energy (eV) [25]. According to Fig. 4 (b), the Eg of CdS-g- $\mathrm{C}_{3} \mathrm{~N}_{4}$ nanocomposite was obtained $2.45 \mathrm{eV}$.

\subsection{Photocatalytic degradation: modeling and optimization}

The photocatalytic activity of $\mathrm{CdS}-\mathrm{g}-\mathrm{C}_{3} \mathrm{~N}_{4}$ was studied in the degradation of CTX under visible light irradiation using the CCD-RSM model. After performing 30 experiments proposed by the software (Table 2), the mathematical model (quadratic polynomial model) was presented as a function of operational parameters and the percentage of ceftriaxone degradation in terms of coded factors as Eq. 3 . 
Degradation $(\%)=67.64+2.18 \mathrm{~A}-0.51 \mathrm{~B}+3.56 \mathrm{C}+4.83 \mathrm{D}-0.52 \mathrm{AB}+2.07 \mathrm{AC}-1.43 \mathrm{AD}-$

$0.72 \mathrm{BC}+0.49 \mathrm{BD}+5.95 \mathrm{CD}-1.51 \mathrm{~A}^{2}-0.62 \mathrm{~B}^{2}+3.07 \mathrm{C}^{2}+0.74 \mathrm{D}^{2}$

To evaluate the accuracy of the proposed model, ANOVA results were used according to Table 3. The F-value of the model is 102.97 and the p-value of the model is less than 0.0001 indicating the excellent adequacy of the proposed model.

The Predicted $\mathrm{R}^{2}$ of 0.9720 is in reasonable agreement with the Adjusted $\mathrm{R}^{2}$ of 0.9801 (i.e., the difference is less than 0.2).Therefore, this model can be used to predict the degradation percentage of ceftriaxone using $\mathrm{CdS}-\mathrm{g}-\mathrm{C}_{3} \mathrm{~N}_{4}$ photocatalyst. Considering the ANOVA results (Table 3) and removing the non-significant terms, Eq. 3 was simplified to Eq. 4.

Degradation $(\%)=67.64+2.18 \mathrm{~A}+3.56 \mathrm{C}+4.83 \mathrm{D}+2.07 \mathrm{AC}-1.43 \mathrm{AD}-0.72 \mathrm{BC}+5.95$

$\begin{array}{llllllllll}\mathrm{CD} & -1.51 & \mathrm{~A}^{2} & -0.62 & \mathrm{~B}^{2} & + & 3.07 & \mathrm{C}^{2} & +0.74 & \mathrm{D}^{2}\end{array}$

The normality of the data is one of the most critical assumptions that must be considered in any experiment and variance analysis. If the residuals have a typical distribution with zero mean and constant variance and also the residuals are independent, the analysis is performed and the adequacy of the proposed model is confirmed.

Table 3. ANOVA results of the designed model.

\begin{tabular}{cccccc}
\hline Source & $\begin{array}{c}\text { Sum of } \\
\text { squares }\end{array}$ & $\begin{array}{c}\text { Degrees of } \\
\text { freedom (Df) }\end{array}$ & $\begin{array}{c}\text { Mean } \\
\text { square }\end{array}$ & F-value & $\begin{array}{c}\text { p-value } \\
\text { Prob > F }\end{array}$ \\
\hline Model & 2062.11 & 14 & 147.29 & 102.97 & $<0.0001$, significant \\
\hline A- $\left[\right.$ CdS- g-C $\left.{ }_{3} \mathrm{~N}_{4}\right]$ & 114.10 & 1 & 114.10 & 79.77 & $<0.0001$ \\
\hline B- $[$ CTX] & 6.33 & 1 & 6.33 & 4.43 & 0.0526 \\
\hline C-pH & 303.53 & 1 & 303.53 & 212.20 & $<0.0001$ \\
\hline D-Time & 560.18 & 1 & 560.18 & 391.63 & $<0.0001$ \\
\hline AB & 4.25 & 1 & 4.25 & 2.97 & 0.1052 \\
\hline AC & 68.27 & 1 & 68.27 & 47.73 & $<0.0001$ \\
\hline AD & 32.58 & 1 & 32.58 & 22.77 & 0.0002 \\
\hline BC & 8.19 & 1 & 8.19 & 5.73 & 0.0302 \\
\hline BD & 3.87 & 1 & 3.87 & 2.71 & 0.1207 \\
\hline
\end{tabular}




\begin{tabular}{cccccc}
\hline $\mathrm{CD}$ & 566.08 & 1 & 566.08 & 395.75 & $<0.0001$ \\
\hline $\mathrm{A}^{2}$ & 62.67 & 1 & 62.67 & 43.81 & $<0.0001$ \\
\hline $\mathrm{B}^{2}$ & 10.43 & 1 & 10.43 & 7.29 & 0.0165 \\
\hline $\mathrm{C}^{2}$ & 258.04 & 1 & 258.04 & 180.40 & $<0.0001$ \\
\hline $\mathrm{D}^{2}$ & 14.91 & 1 & 14.91 & 10.42 & 0.0056 \\
\hline Residual & 21.46 & 15 & 1.43 & & 0.9825 not significant \\
\hline Lack of Fit & 6.35 & 10 & 0.64 & 0.21 & \\
\hline Pure Error & 15.10 & 5 & 3.02 & & \\
\hline Cor Total & 2083.57 & 29 & & Adjusted $\mathrm{R}^{2}=0.9801$ \\
\hline Predicted $\mathrm{R}^{2}=0.9720$ & & &
\end{tabular}

The normal plot of residuals vs. internally residuals was illustrated in Fig. 5.

$<$ Fig.5>

As can be seen, the points are on a straight line and the distribution of the residuals has a slight deviation. Therefore, the error variance is homogeneous and there is no obvious scatter. Examining data independence is another factor that should be considered regarding the adequacy of the model. In this regard, the plot of residuals versus run was shown in Fig. 6.

$<$ Fig.6>

According to Fig. 6, this plot does not show a specific trend. The selected model is valid for examining the relationship between the obtained response and the selected independent variables.

Considering Eq. 4, the three-dimensional (3D) response surfaces diagrams (response levels) related to the effects of variables (amount of photocatalyst, $\mathrm{pH}$ and irradiation time) on the response (percentage of degradation) are shown in Fig. 7.

<Fig.7>

The response surface diagram in Fig. 7 (a) shows the effect of the concentration of CdS-g$\mathrm{C}_{3} \mathrm{~N}_{4}$ nanocomposite (A) and the irradiation time (D) on the CTX degradation percentage. The two parameters of initial antibiotic concentration and $\mathrm{pH}$ are $10 \mathrm{mg} / \mathrm{L}$ and 9, 
respectively. It is observed that with increasing the concentration of photocatalyst and the irradiation time, the percentage of degradation also increases.

As the irradiation time and the amount of photocatalyst increases, the amount of produced electrons and holes increases, resulting in more active species $\left(\mathrm{OH}, \mathrm{O}_{2}^{--}\right)$being formed and the degradation efficiency increases.

$\mathrm{pH}$ is one of the effective parameters in the photocatalytic degradation of CTX. As shown in Fig. 7 (b) and 7 (c), the degradation efficiency increases as the $\mathrm{pH}$ becomes alkaline. According to the literatures $[8,44]$, high degradation efficiency of CTX in alkaline condition can be influenced by two factors. With increasing $\mathrm{pH}$, the amount of $\mathrm{OH}^{-}$ions increased which eventually led to an increase in $\mathrm{OH} \cdot[8,44]$. Also, in alkaline $\mathrm{pH}$, hydrolysis of CTX is intensified due to the instability of the beta-lactam ring [45].

After investigating the role of operational variables, an optimization process was performed. The results proposed that $92.55 \%$ of CTX antibiotic degrades at the initial CTX concentration of $15 \mathrm{mg} / \mathrm{L}, 0.06 \mathrm{~g} / \mathrm{L}$ of $\mathrm{CdS}-\mathrm{g}-\mathrm{C}_{3} \mathrm{~N}_{4}$ photocatalyst, $\mathrm{pH}=10.5$, and $81 \mathrm{~min}$ visible light irradiation. The experimental analysis was carried out under the proposed optimal condition and $91.97 \%$ was obtained for photodegradation of CTX antibiotic. It is considered that the observed photodegradation percentage is in good agreement with the predicted theoretical value, which confirmed the validity of the model.

\subsection{Photodegradation mechanism}

The photodegradation mechanism for CTX decomposition using $\mathrm{CdS}-\mathrm{g}-\mathrm{C}_{3} \mathrm{~N}_{4}$ photocatalyst under visible light was schematically shown in Fig. 8. The electrons of $\mathrm{CdS}$ and $\mathrm{g}-\mathrm{C}_{3} \mathrm{~N}_{4}$ were excited simultaneously during visible light. The relevant energy correspondence between $\mathrm{CdS}$ and the $\mathrm{g}-\mathrm{C}_{3} \mathrm{~N}_{4}$ caused the transmission of the electrons from the conduction band (CB) of $\mathrm{g}-\mathrm{C}_{3} \mathrm{~N}_{4}(-1.11 \mathrm{eV}$ vs. NHE) to the $\mathrm{CB}$ of $\mathrm{CdS}(-0.26 \mathrm{eV}$ vs. NHE) and the holes from the valence band (VB) of $\mathrm{CdS}(1.98 \mathrm{eV}$ vs. $\mathrm{NHE})$ to the $\mathrm{VB}$ of $\mathrm{g}-\mathrm{C}_{3} \mathrm{~N}_{4}(1.54 \mathrm{eV}$ vs. $\mathrm{NHE})$. 
Therefore, the $\mathrm{CdS}$ and $\mathrm{g}-\mathrm{C}_{3} \mathrm{~N}_{4}$ formed the type -II heterojunction photocatalyst system, which accelerated the separation of charge carriers. The rapid transfer of charge carriers and their effective separation from each other, which ultimately leads to an increase in the degradation efficiency of CTX.

The $\mathrm{CB}$ of $\mathrm{CdS}$ and $\mathrm{g}-\mathrm{C}_{3} \mathrm{~N}_{4}$ is agreeable with the redox potential of $\mathrm{O}_{2} / \mathrm{O}_{2} \cdot-(-0.046 \mathrm{eV}$ vs. NHE). So, the electrons of $\mathrm{CB}$ in the $\mathrm{CdS}$ and $\mathrm{g}-\mathrm{C}_{3} \mathrm{~N}_{4}$ produce superoxide anions $\left(\mathrm{O}_{2}{ }^{-}\right)$. The electrons in the $\mathrm{CB}$ of $\mathrm{CdS}$ and $\mathrm{g}-\mathrm{C}_{3} \mathrm{~N}_{4}$ reacted with the $\mathrm{O}_{2}$ molecules and $\mathrm{H}^{+}$, producing hydrogen peroxide $\left(\mathrm{H}_{2} \mathrm{O}_{2}\right)$. The $\mathrm{H}_{2} \mathrm{O}_{2}$ produced $\mathrm{OH}$, which reacted with CTX molecules and produced $\mathrm{CO}_{2}, \mathrm{H}_{2} \mathrm{O}$. On the other hand, produced holes will be directly reacted with CTX molecules [27].

$<$ Fig. $>$

According to the proposed mechanism, superoxide radicals $\left(\mathrm{O}_{2}^{--}\right)$, hydroxide radicals $(\mathrm{OH})$, and produced holes $\left(\mathrm{h}^{+}\right)$are the main species in the photocatalytic degradation of the antibiotic ceftriaxone. Based on the literatures, $\mathrm{OH}$ and $\mathrm{h}^{+}$were more active than $\mathrm{O}_{2}{ }^{-}$for decomposition of CTX in the presence of $\mathrm{g}-\mathrm{C}_{3} \mathrm{~N}_{4}$ nanocomposites [46].

\subsection{Kinetic studies}

To evaluate the kinetics of the photocatalytic removal of ceftriaxone in the presence of CdSg- $\mathrm{C}_{3} \mathrm{~N}_{4}$ nanocomposite, the experiments were performed under the optimal conditions proposed by the software for 80 min. The Langmuir-Hinshelwood (L-H) model [47] (Eq. 5), one of the most common kinetic models for the study of heterogeneous photocatalytic systems, was used to investigate the process kinetics.

$\mathrm{R}=$

$\frac{\mathrm{dC}}{\mathrm{dt}} \quad \frac{\mathrm{kKC}}{1+\mathrm{KC}_{0}}$

Where $\mathrm{R}$ is reaction rate, $\mathrm{k}$ is the reaction rate constant $\left(\mathrm{min}^{-1} \mathrm{mgL}^{-1}\right), \mathrm{K}$ is the adsorption equilibrium constant $\left(\mathrm{Lmg}^{-1}\right), \mathrm{t}$ is the irradiation time $(\mathrm{min}), \mathrm{C}_{0}$ and $\mathrm{C}_{\mathrm{t}}$ are the pollutant 
concentrations $\left(\mathrm{mgL}^{-1}\right)$ at the beginning and time t, respectively. By integrating Eq. 6 and defining the apparent rate constant $\left(\mathrm{k}_{\mathrm{app}}\right)$, the equation becomes quasi-first-order kinetics (Eq.7) [48].

$\operatorname{Ln} \frac{\mathrm{C}_{0}}{\mathrm{C}_{\mathrm{t}}}=-\mathrm{k}_{\mathrm{app}} \mathrm{t}$

The $\operatorname{Ln} \frac{C_{0}}{C_{t}}$ vs. irradiation time (t) diagram was illustrated in Fig. 9. Using the slope of Fig. 9, kapp was obtained for the photocatalytic degradation of CTX under optimal conditions equal to $0.0336 \mathrm{~min}^{-1}$.

<Fig.9>

\section{Conclusion}

In this study, the efficiency of the as-synthesized $\mathrm{CdS}-\mathrm{g}-\mathrm{C}_{3} \mathrm{~N}_{4}$ nanocomposite for photocatalytic removal of the ceftriaxone antibiotic under visible light was modeled and optimized using the response surface methodology-central composite design (RSM-CCD) model. The results showed that the amount of photocatalyst $\left[\mathrm{CdS}-\mathrm{g}-\mathrm{C}_{3} \mathrm{~N}_{4}\right], \mathrm{pH}$ and irradiation time are the most influential the degradation efficiency factors. The higher the amount of these factors, the higher the decomposition efficiency. The highest percentage of degradation (92.55\%) was obtained in the initial concentration of ceftriaxone $15 \mathrm{mg} / \mathrm{L}$, in the presence of $0.06 \mathrm{~g} / \mathrm{L}$ of photocatalyst, $\mathrm{pH}=10.5$, and irradiation time of $81 \mathrm{~min}$ as optimal conditions.

Process kinetics evaluation also showed that the photocatalytic removal of ceftriaxone in the optimal conditions proposed by the software follows the quasi-first-order model with an apparent rate constant of $0.0336 \mathrm{~min}^{-1}$. The straightforward synthesis of $\mathrm{CdS}-\mathrm{g}-\mathrm{C}_{3} \mathrm{~N}_{4}$ nanocomposite (chemical precipitation) and its high performance in the photocatalytic degradation of ceftriaxone under visible light make it recommended for treating effluents containing this drug. 


\section{Declaration of interests}

The authors declare that they have no known competing financial interests or personal relationships that could have appeared to influence the work reported in this paper.

\section{References}

1. S. Majumder, S. Chatterjee, P. Basnet and J. Mukherjee, Environ. Nanotechno. Monit. Manag. 14, 100386 (2020).

2. N. Ahmadpour, M. H. Sayadi, S. Sobhani and M. Hajiani, J. Environ. Manage. 271, 110964 (2020).

3. X. Shi, A. Karachi, M. Hosseini, M. S. Yazd, H. Kamyab, M. Ebrahimi and Z. Parsaee, Ultrason. Sonochem. 68, 104460 (2020).

4. X. He, V. Nguyen, Z. Jiang, D. Wang, Z. Zhu and W.-N. Wang, Catal. Sci. Technol. 8, 2117 (2018).

5. J. Hong, D. K. Hwang, R. Selvaraj and Y. Kim, J. Ind. Eng. Chem. 79, 473 (2019).

6. M. J. F. Calvete, G. Piccirillo, C. S. Vinagreiro and M. M. Pereira, Coord. Chem. Rev. 395, 63 (2019).

7. G. Lofrano, G. Libralato, S. K. Sharma and M. Carotenuto, in Nanotechnologies for Environmental Remediation: Applications and Implications, eds. by G. Lofrano, G. Libralato and J. Brown, (Springer, Cham, 2017), p. 221.

8. M. Shokri, G. Isapour, S. Shamsvand and B. Kavousi, J. Mater. Environ. Sci. 7, (2016) 2843.

9. S. Y. Hashemi, M. Yegane Badi, H. Pasalari, A. Azari, H. Arfaeinia and A. Kiani, Int. J. Environ. Anal. Chem. (2020) http:// doi.org/ 10.1080/03067319.2020.1817909.

10. Y. Zhao, X. Liang, Y. Wang, H. Shi, E. Liu, J. Fan and X. Hu, J. Colloid Interface Sci. 523, 7 (2018). 
11. Y. Zhao, Y. Wang, E. Liu, J. Fan and X. Hu, Appl. Surf. Sci. 436, 854 (2018).

12. F. Yu, Y. Sun, M. Yang and J. Ma, J. Hazard. Mater. 374, 195 (2019).

13. Y. Gao, Y. Li, L. Zhang, H. Huang, J. Hu, S. M. Shah and X. Su, J. Colloid Interface Sci. 368, 540 (2012).

14. E. M. Cuerda-Correa, M. F. Alexandre-Franco and C. Fernández-González, Water, 12 (2020).

15. Z.-Y. Lu, Y.-L. Ma, J.-T. Zhang, N.-S. Fan, B.-C. Huang and R.-C. Jin, J.Water Process. Eng. 38, 101681 (2020).

16. H. Zhao, G. Li, F. Tian, Q. Jia, Y. Liu and R. Chen, Chem. Eng. J. 366, 468 (2019).

17. S. Dong, L. Cui, W. Zhang, L. Xia, S. Zhou, C. K. Russell, M. Fan, J. Feng and J. Sun, Chem. Eng. J. 384, 123279 (2020).

18. P. Gholami, A. Khataee, R. D. C. Soltani, L. Dinpazhoh and A. Bhatnagar, J. Hazard. Mater. 382, 121070 (2020).

19. R. Tangsiri and A. Nezamzadeh-Ejhieh, Chem. Phys. Lett. 758, 137919 (2020).

20. O. Sacco, V. Vaiano, L. Rizzo and D. Sannino, Chem.Eng. Process. 137, 12 (2019).

21. V. T. Quyen, J. Kim, P.-M. Park, P. T. Huong, N. M. Viet and P. Q. Thang, J. Environ. Chem. Eng. (2020) https://doi.org/10.1016/j.jece.2020.104737.

22. S. Zhang, J. Yi, J. Chen, Z. Yin, T. Tang, W. Wei, S. Cao and H. Xu, Chem. Eng. J. 380, 122583 (2020).

23. K. Zhang, W. Meng, S. Wang, H. Mi, L. Sun and K. Tao, New J. Chem. 44, 472 (2020).

24. M. Nagamine, M. Osial, K. Jackowska, P. Krysinski and J. Widera-Kalinowska, J. Mar. Sci. Eng, 8 (2020).

25. A. G. Khosroshahi and A. Mehrizad, J. Mol. Liq. 275, 629 (2019).

26. A. İ. Vaizoğullar, J. Inorg. Organomet. Polym. Mater. 30, 4129 (2020). 
27. B. Shao, X. Liu, Z. Liu, G. Zeng, W. Zhang, Q. Liang, Y. Liu, Q. He, X. Yuan, D. Wang, S. Luo and S. Gong, Chem. Eng. J. 374, 479 (2019).

28. G. Afreen, M. Shoeb and S. Upadhyayula, Mater. Sci. Eng. C. 108, 110372 (2020).

29. M. Kaur, S. K. Mehta and S. K. Kansal, J. Environ. Chem. Eng. 6, 3631 (2018).

30. P. Huo, Y. Tang, M. Zhou, J. Li, Z. Ye, C. Ma, L. Yu and Y. Yan, J. Ind. Eng. Chem. 37, 340 (2016).

31. M.-f. Li, Y.-g. Liu, G.-m. Zeng, N. Liu and S.-b. Liu, Chemosphere 226, 360 (2019).

32. L. Wang, K. Wang, T. He, Y. Zhao, H. Song and H. Wang, ACS Sustain. Chem. Eng. 8, 16048 (2020).

33. T. O. Ajiboye, O. A. Oyewo and D. C. Onwudiwe, J. Inorg. Organomet. Polym. Mater. (2020) http://doi.org/10.1007/s10904-020-01803-3.

34. S. Moorthy, G. Moorthy and K. Swaminathan, J. Inorg. Organomet. Polym. Mater. 30, 4664 (2020).

35. S. Cao, Z. Jiao, H. Chen, F. Jiang and X. Wang, J. Photochem. Photobiol. A. 364, 22 (2018).

36. J. Su, X. Wu, C. Zhang, H. Wang, M. Zhang, J. Zhang, Y. Jia, Y. Cui, X. Tong, J. Shang and C. Zhang, J. Wuhan Univ.Technol.Mater. Sci. Ed. 35, 99 (2020).

37. N. Zhang, X. Li, Y. Wang, B. Zhu and J. Yang, Ceram. Int. 46, 20974 (2020).

38. E. B. Yazdani and A. Mehrizad, J. Mol. Liq. 255, 102 (2018).

39. S. Bhalerao, S. Arbuj, S. Rane, J. Ambekar and U. Mulik, Nanosci. Nanotechnol. Lett. 6, 204 (2014).

40. M. B. Shekardasht, M. H. Givianrad, P. Gharbani, Z. Mirjafary and A. Mehrizad, Diam. Relat. Mater. 109, 108008 (2020).

41. B. Tahir, M. Tahir, N. Aishah and N. A. Saidina Amin, Chem. Eng. Trans., 56 (2017).

42. Ch. Zhang, Y. Lu, Q. Jiang, J. Hu, Nanotechnology. 27, 355402 (2016). 
43. X. Liu, Y. Liu, W. Zhang, Q. Zhong, X. Ma, Mate. Sci. Semicond. Process. 105, $104734(2020)$.

44. C.H. Chiou, C.Y. Wu, R.S. Juang, Chem. Eng. J. 139, 322 (2008).

45. M. R. Usman, A. Prasasti, S. Islamiah, A. N. Firdaus, A. W. Marita, S. Fajriyah and E. F. Yanti. J. Kimia Valensi. (2020) http:// doi.org/10.15408/jkv.v6i1.12475.

46. Y. Zhao, Y. Wang, H. Shi, E. Liu, J. Fan, X. Hu, Mater. Lett. 231, 150 (2018).

47. X. Zheng, D. Zhang, Y. Gao, Y. Wu, Q. Liu and X. Zhu, Inorg. Chem. Commun. 110, 107589 (2019).

48. H. Kais, N. Y. Mezenner, M. Trari and F. Madjene, Russ. J. Phys. Chem. A. 93, 2834 (2019).

\section{Figures Caption:}

Fig.1. XRD patterns of (a) pure $\mathrm{CdS}$ (b) pristine g- $\mathrm{C}_{3} \mathrm{~N}_{4}$ (c) $\mathrm{CdS}-\mathrm{g}-\mathrm{C}_{3} \mathrm{~N}_{4}$ nanocomposite.

Fig.2. FE-SEM images and EDX results of (a) pure $\mathrm{CdS}$ (b) pristine $\mathrm{g}-\mathrm{C}_{3} \mathrm{~N}_{4}$ (c) $\mathrm{CdS}-\mathrm{g}-\mathrm{C}_{3} \mathrm{~N}_{4}$ nanocomposite.

Fig. 3. TEM image of CdS-g- $\mathrm{C}_{3} \mathrm{~N}_{4}$ nanocomposite.

Fig. 4. (a) UV-Vis absorbance spectrum (b) $(\mathrm{Ah} v)^{2}$ vs. hv of CdS-g-C $3 \mathrm{~N}_{4}$ nanocomposite.

Fig. 5. The normal plot of probability vs. internally residuals.

Fig. 6. The plot of residuals versus run numbers.

Fig. 7. Response surface plots of the CTX photodegradation percentage as a function of (a) concentration of CdS-g- $\mathrm{C}_{3} \mathrm{~N}_{4}$ nanocomposite and time (b) concentration of $\mathrm{CdS}-\mathrm{g}-\mathrm{C}_{3} \mathrm{~N}_{4}$ nanocomposite and $\mathrm{pH}(\mathrm{c})$ time and $\mathrm{pH}$.

Fig.8.The schematic illustration of photodegradation mechanism for CTX decomposition using CdS-g- $\mathrm{C}_{3} \mathrm{~N}_{4}$ photocatalyst under visible light.

Fig.9. Ln $\frac{\mathrm{C}_{0}}{\mathrm{C}_{\mathrm{t}}}$ vs. time diagram for the photocatalytic degradation of CTX under optimal conditions $\left(\left[\mathrm{CdS}-\mathrm{g}-\mathrm{C}_{3} \mathrm{~N}_{4}\right]=0.06 \mathrm{~g} / \mathrm{L},[\mathrm{CTX}]_{0}=15 \mathrm{mg} / \mathrm{L}, \mathrm{pH}=10.5\right)$. 


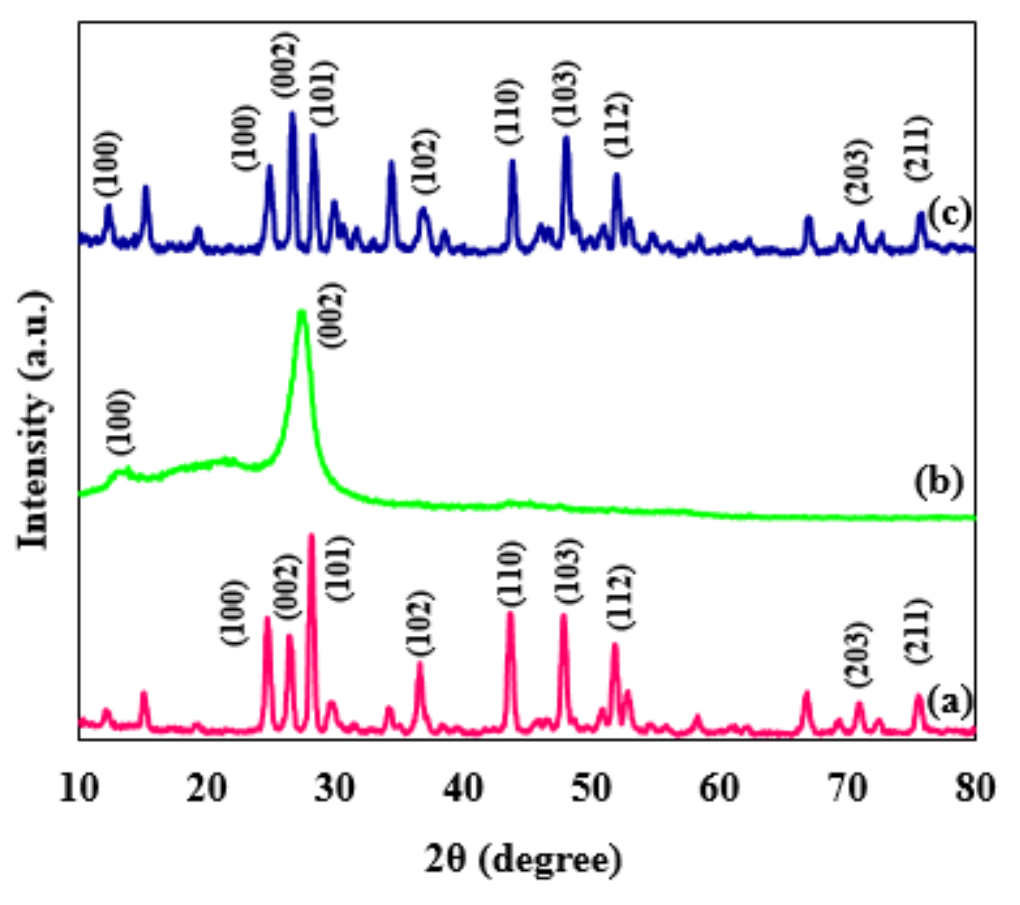

Fig.1. 

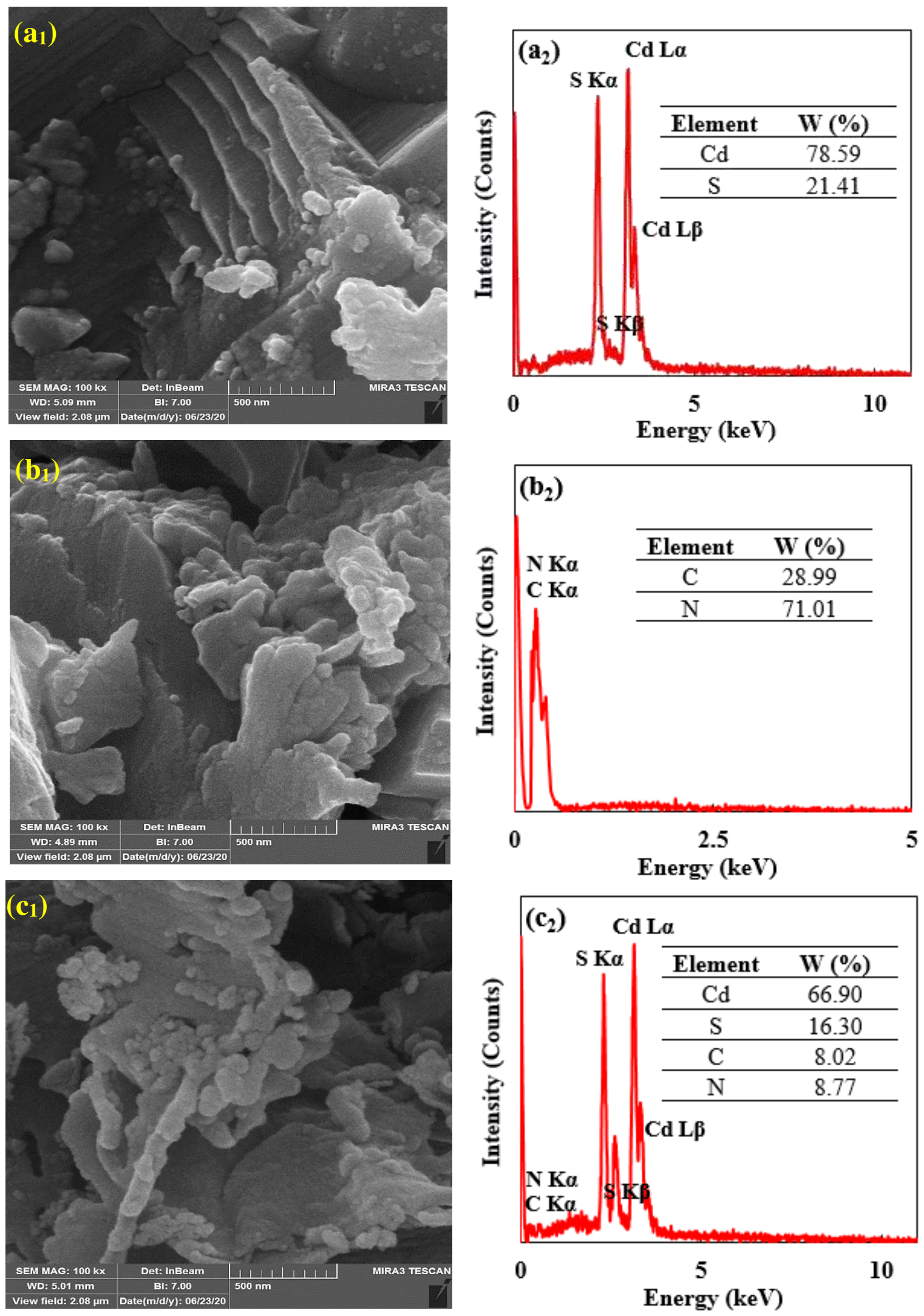

Fig.2. 


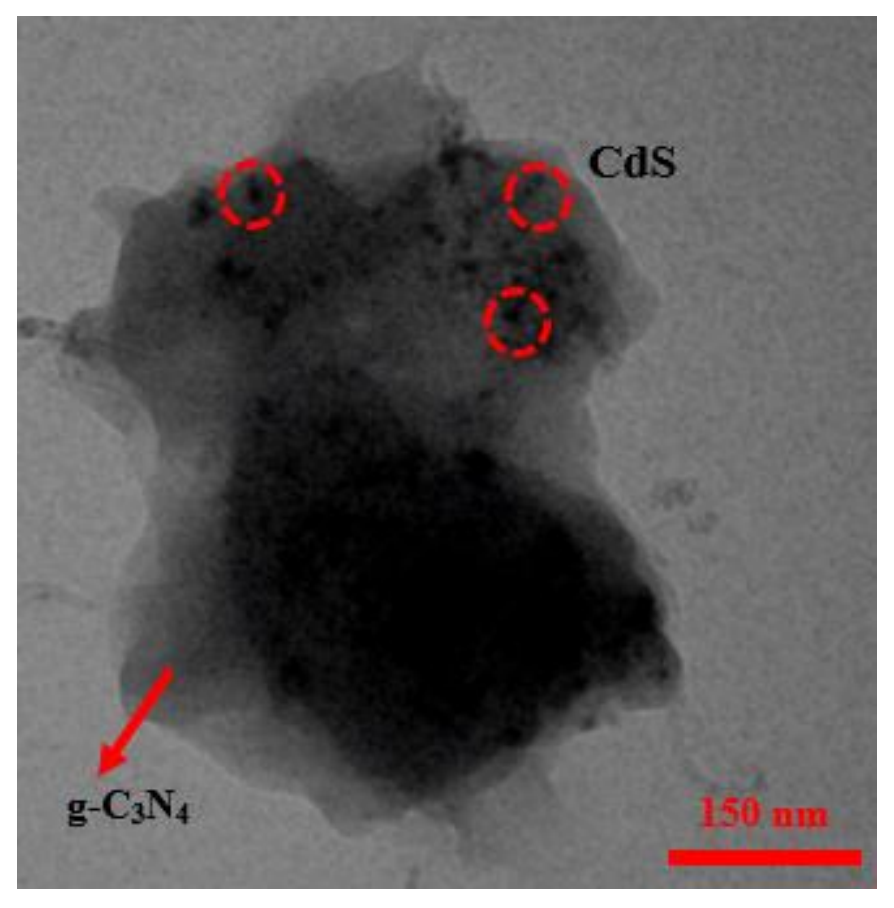

Fig.3. 

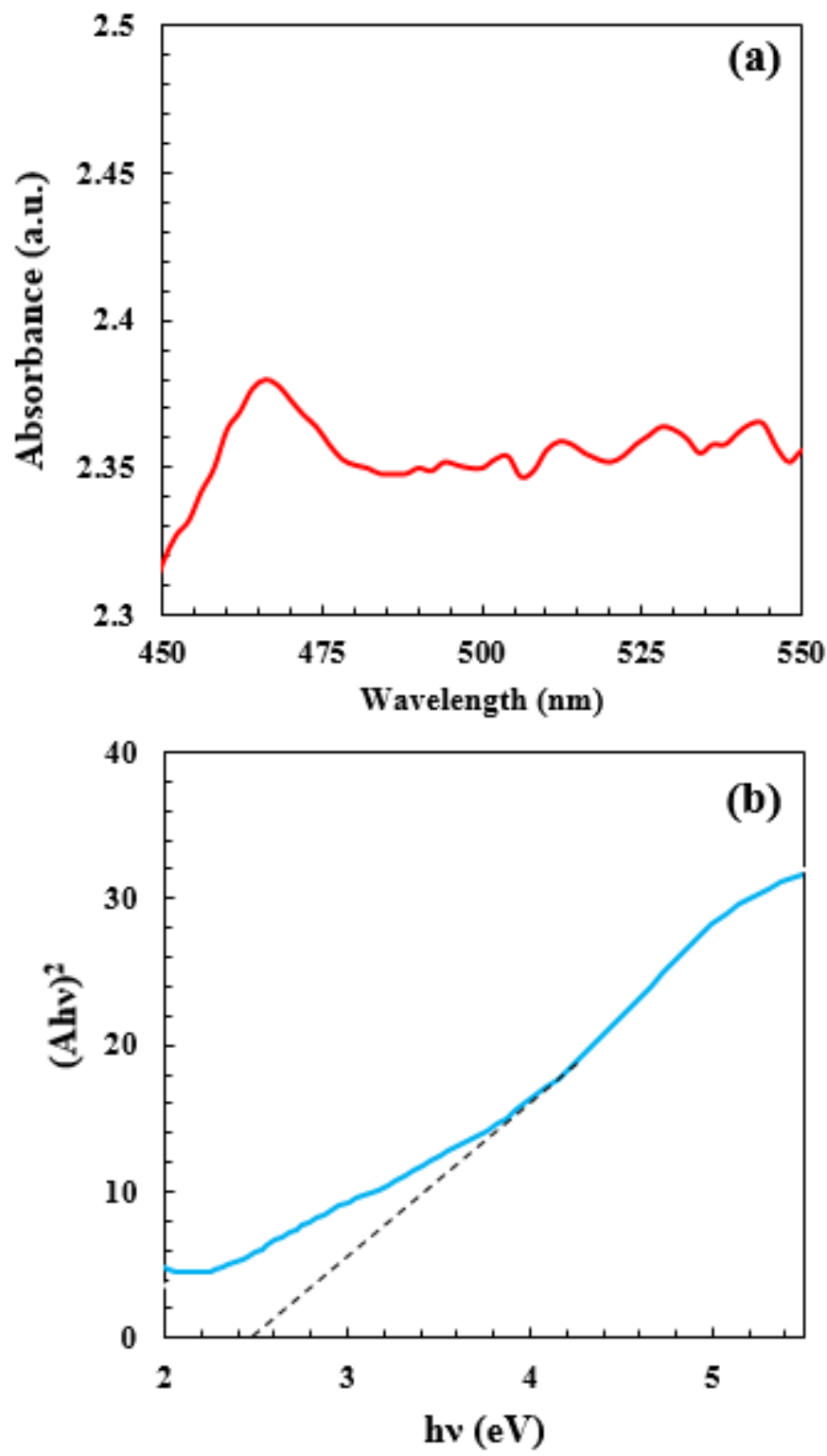

Fig.4 


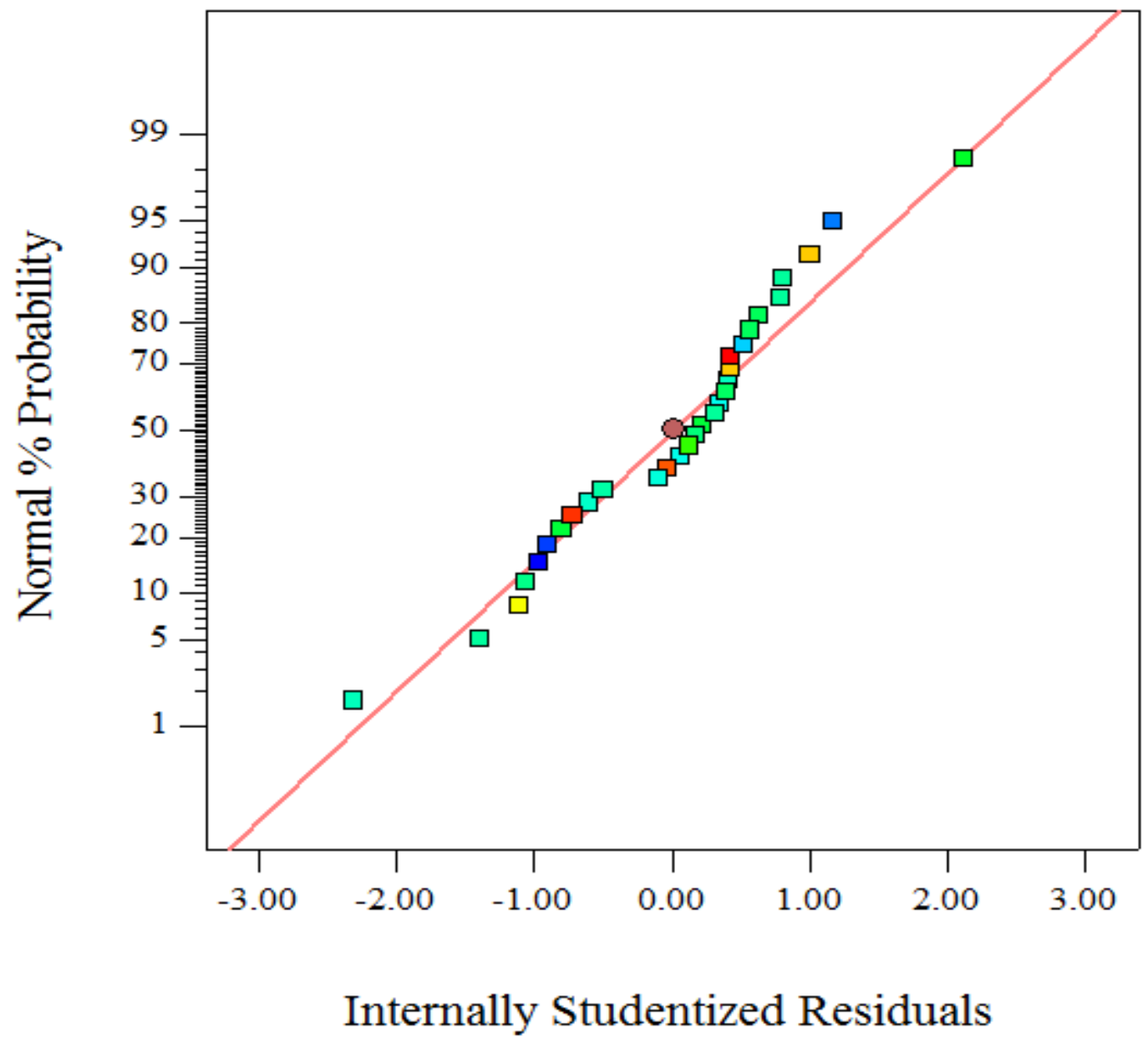

Fig. 5. 


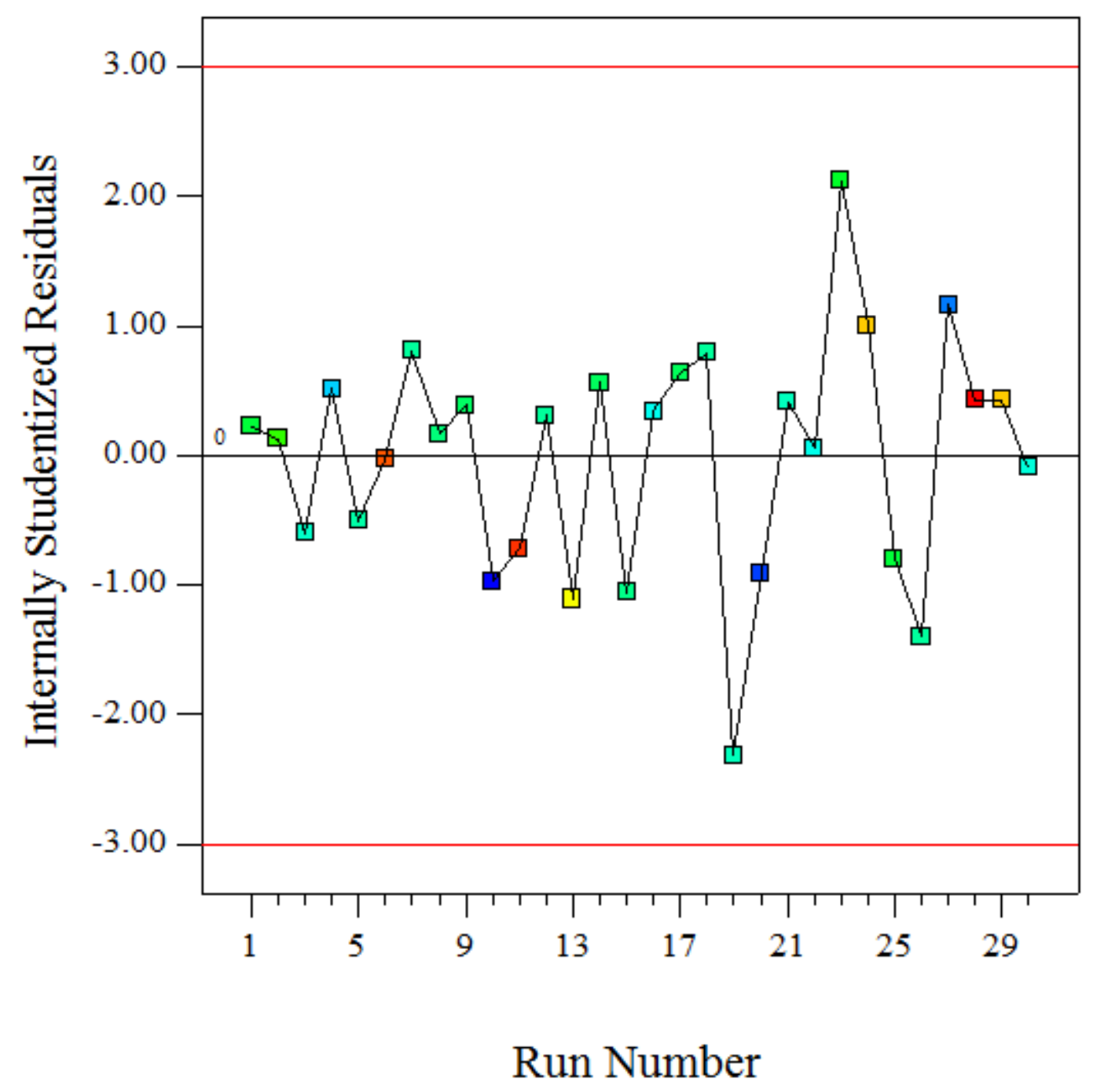

Fig. 6. 

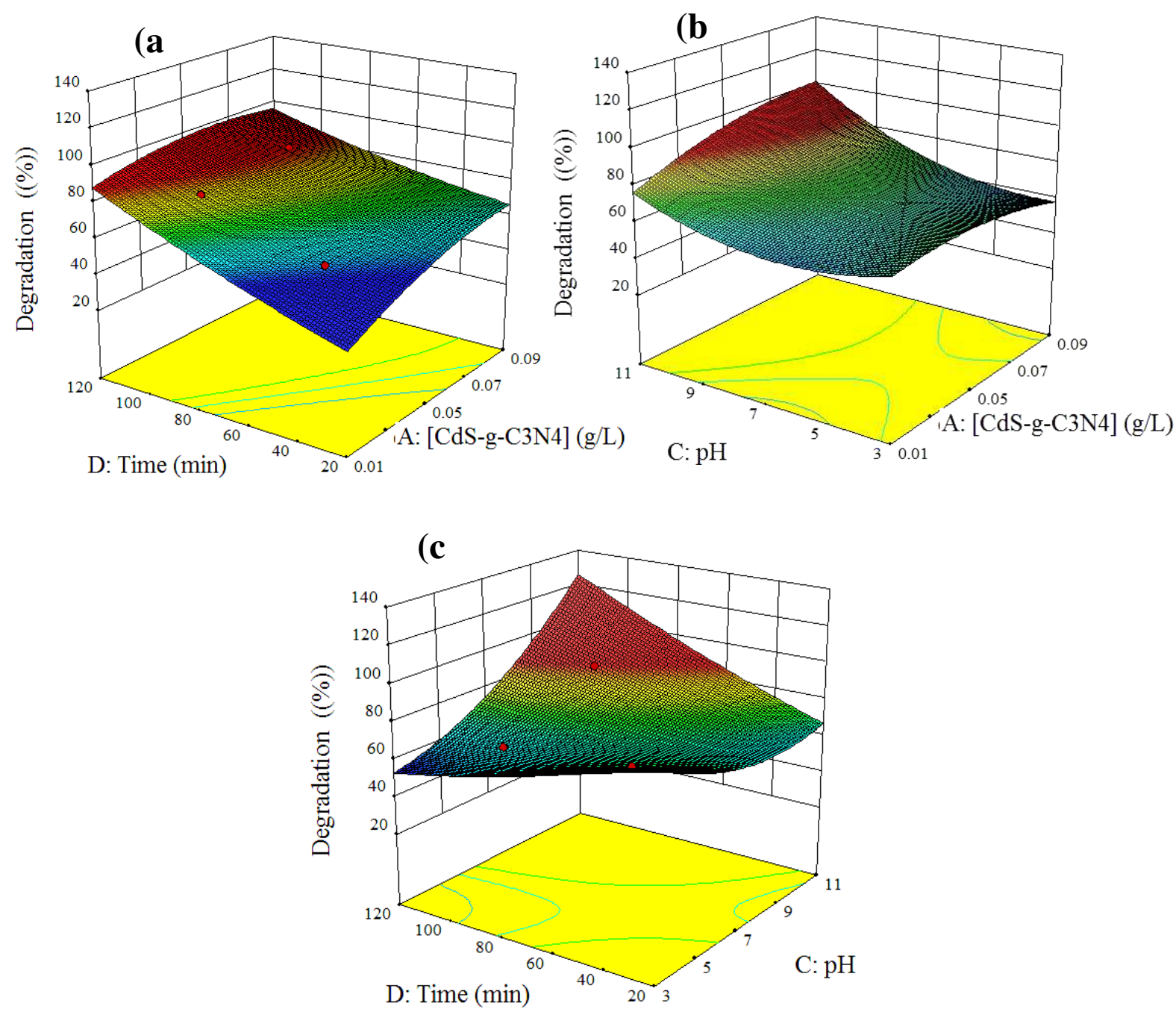

Fig.7. 


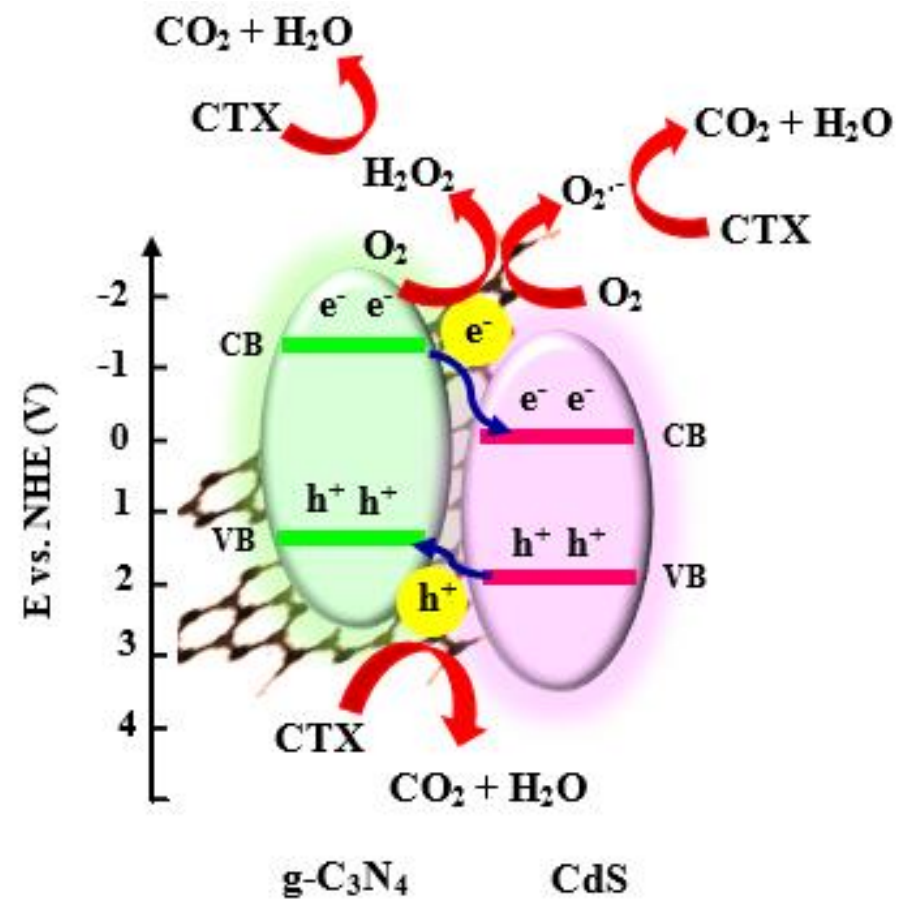

Fig.8. 


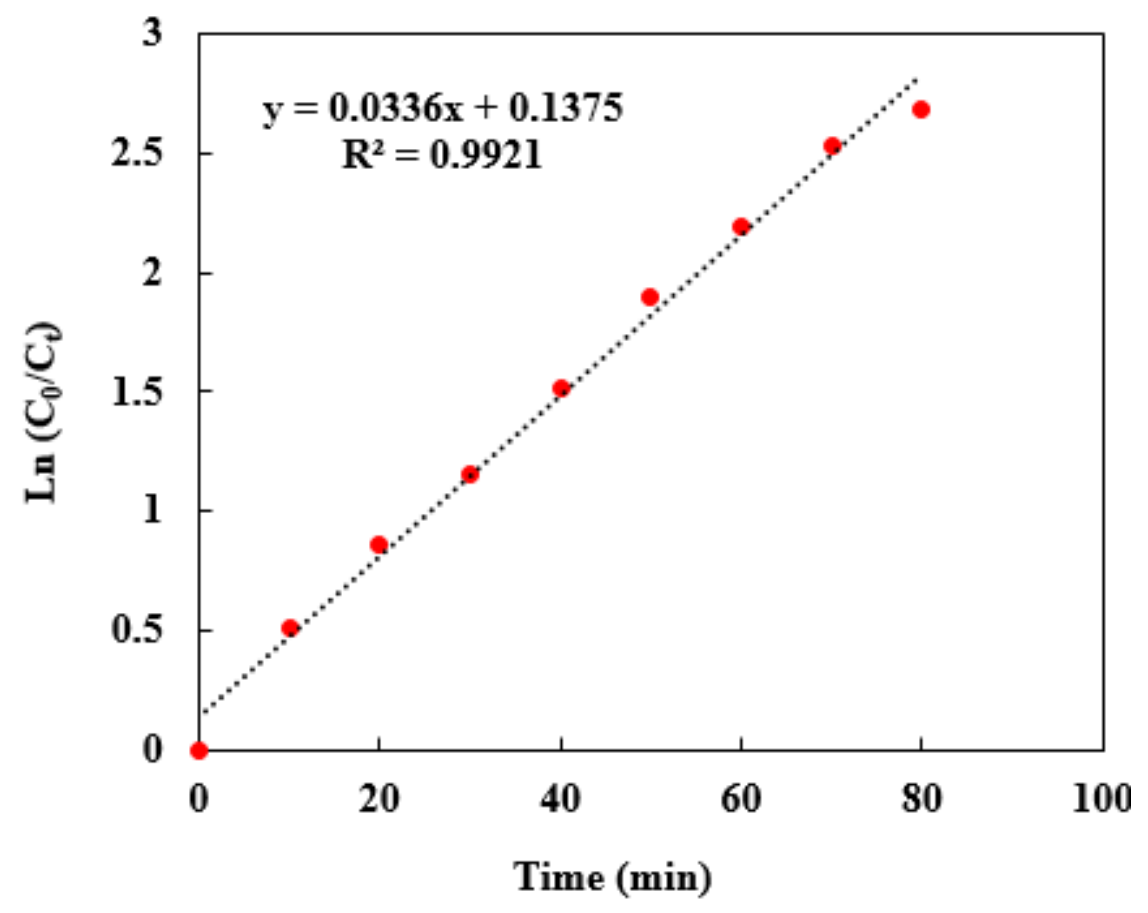

Fig.9. 
Figures

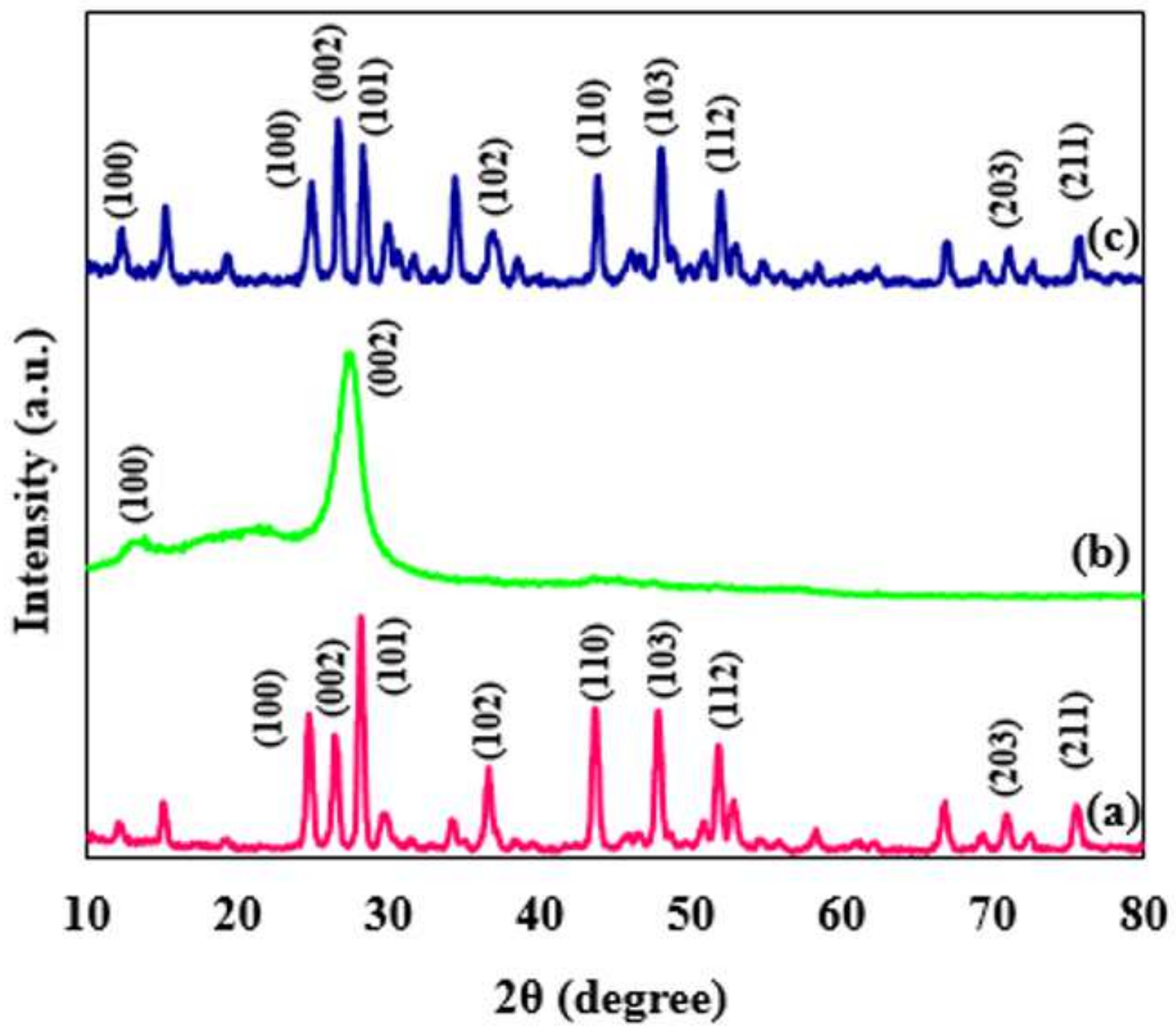

Figure 1

XRD patterns of (a) pure CdS (b) pristine g-C3N4 (c) CdS-g-C3N4 nanocomposite. 

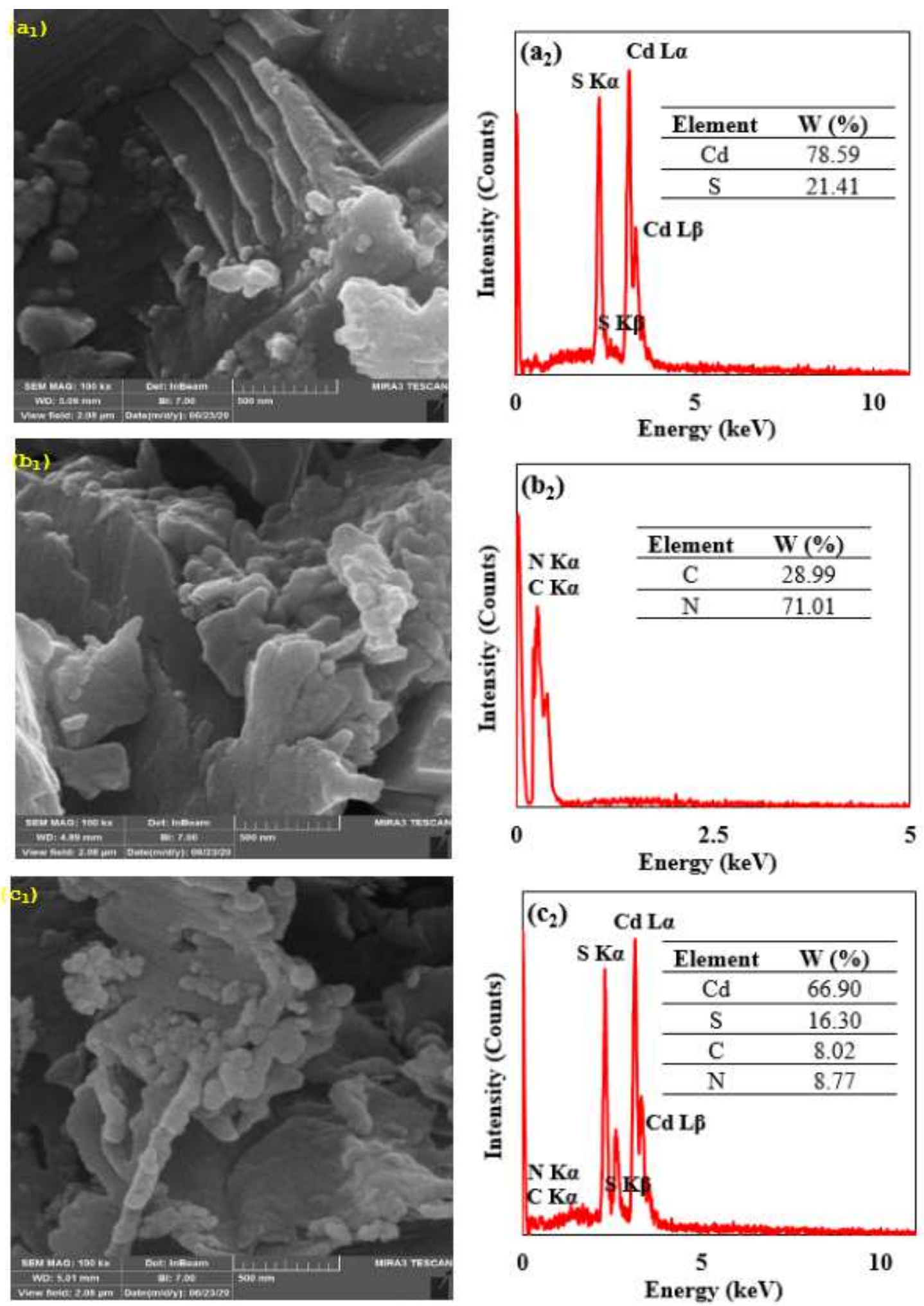

Figure 2

FE-SEM images and EDX results of (a) pure CdS (b) pristine g-C3N4 (c) CdS-g-C3N4 nanocomposite. 


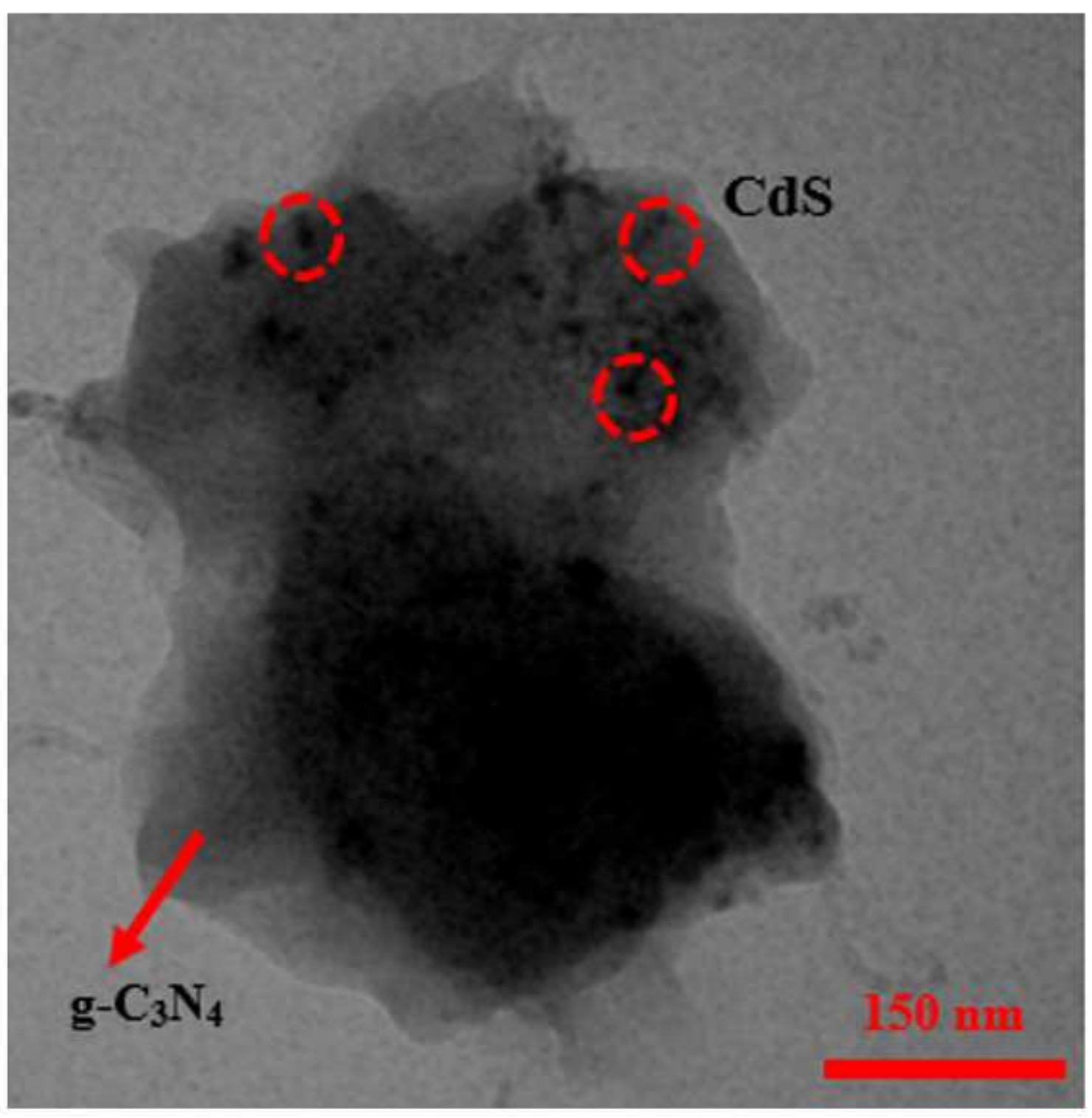

Figure 3

TEM image of CdS-g-C3N4 nanocomposite. 

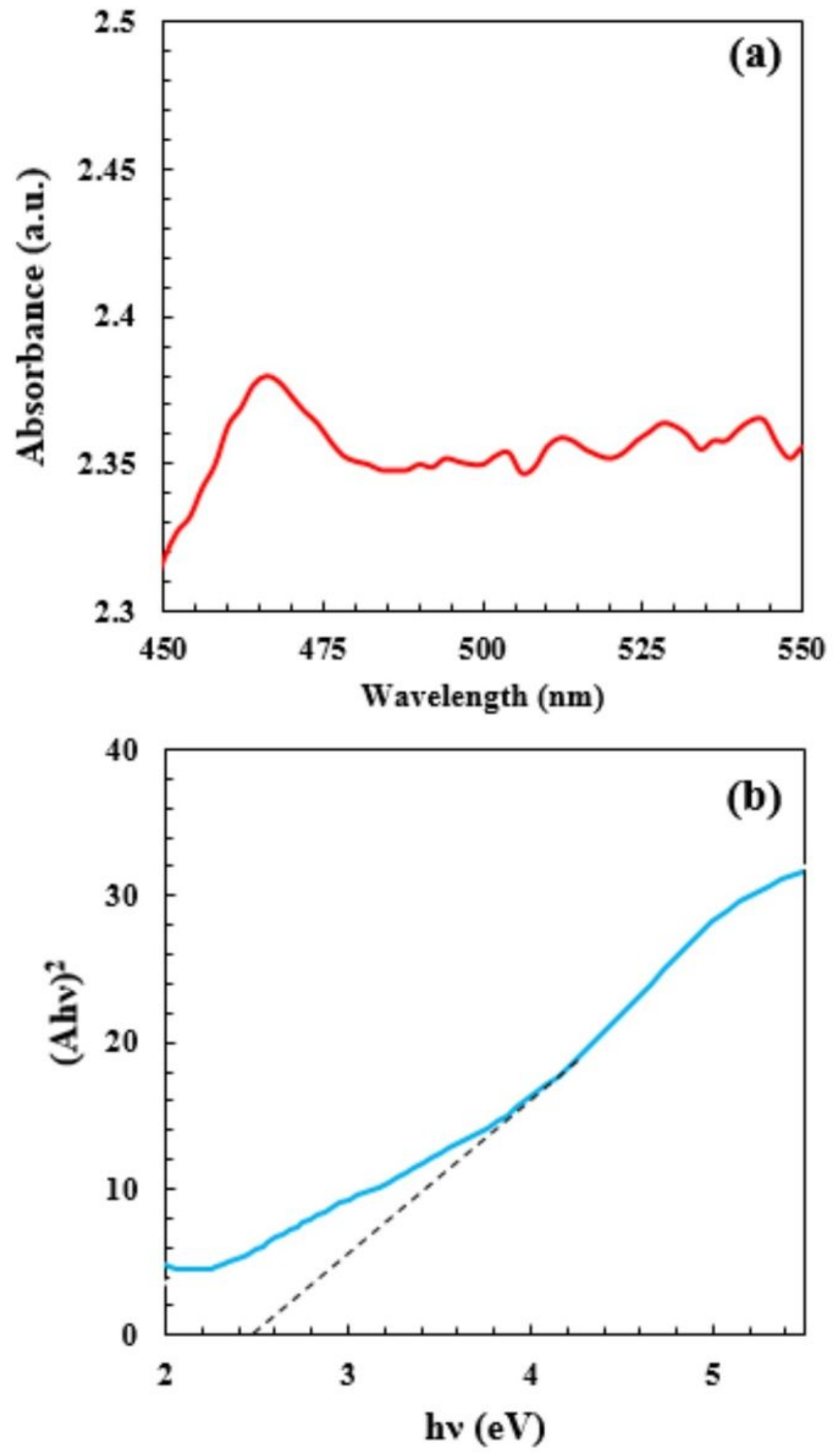

Figure 4

(a) UV-Vis absorbance spectrum (b) (Ahv)2 vs. hv of CdS-g-C3N4 nanocomposite. 


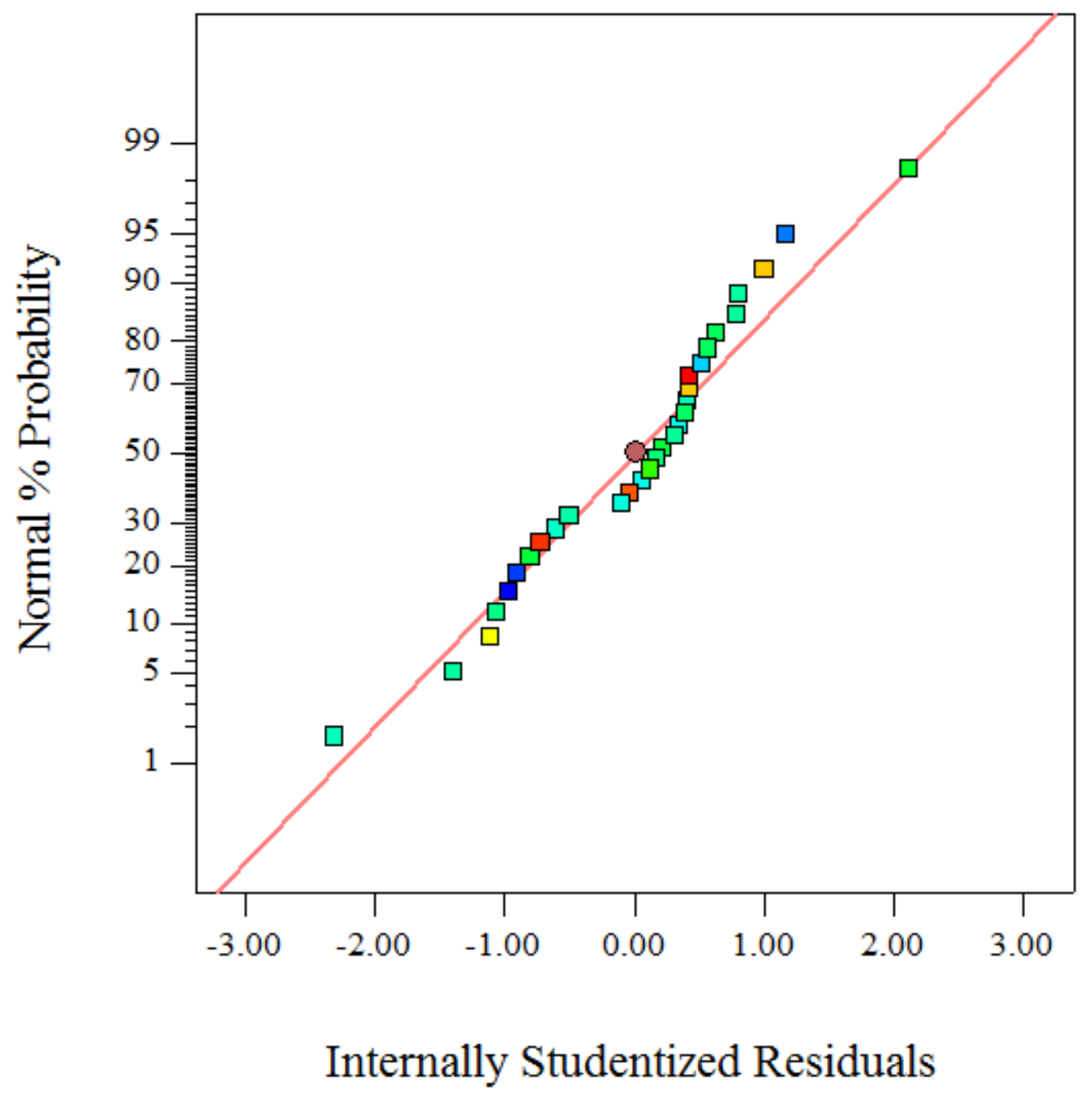

Figure 5

The normal plot of probability vs. internally residuals. 


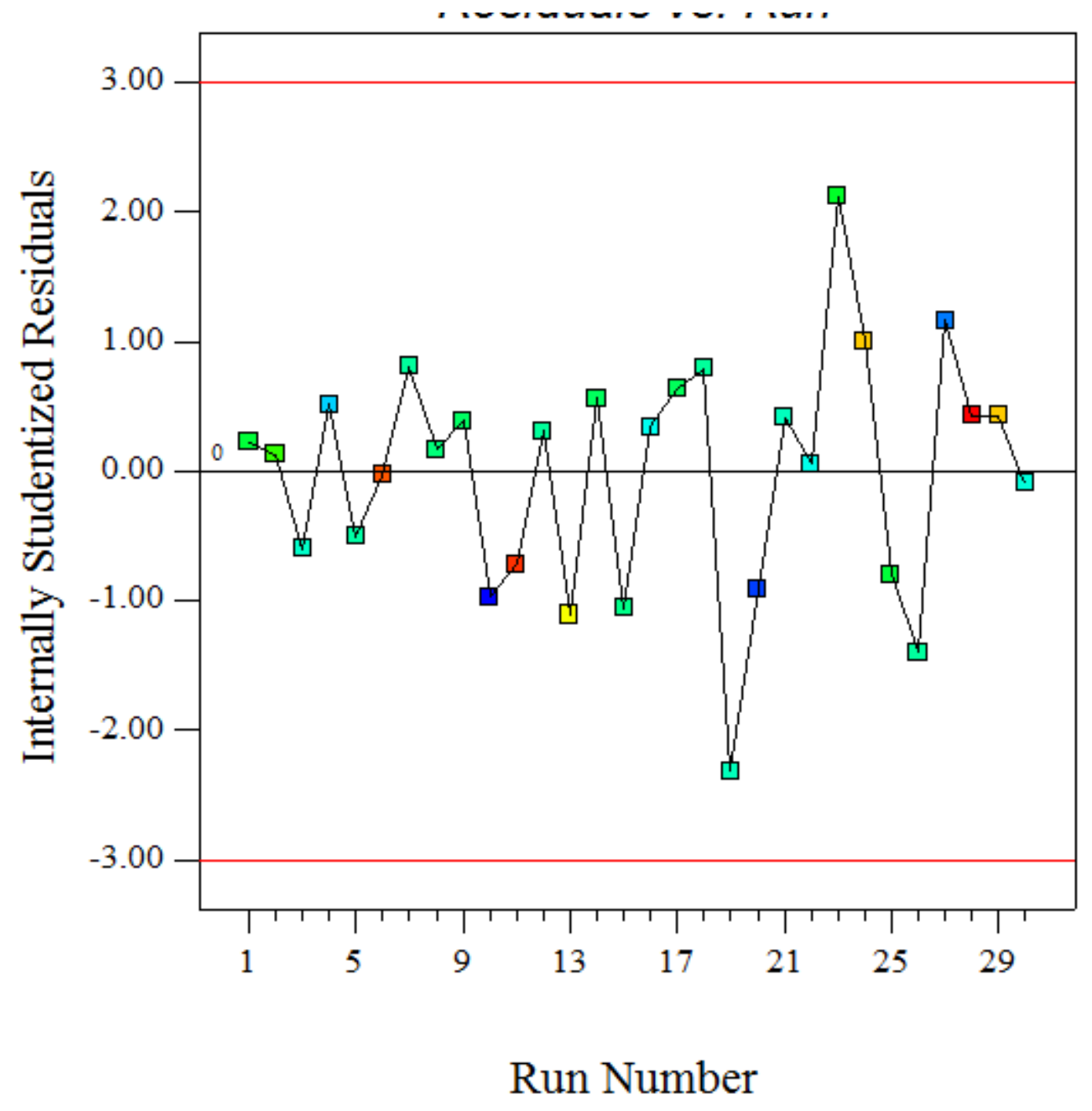

Figure 6

The plot of residuals versus run numbers. 

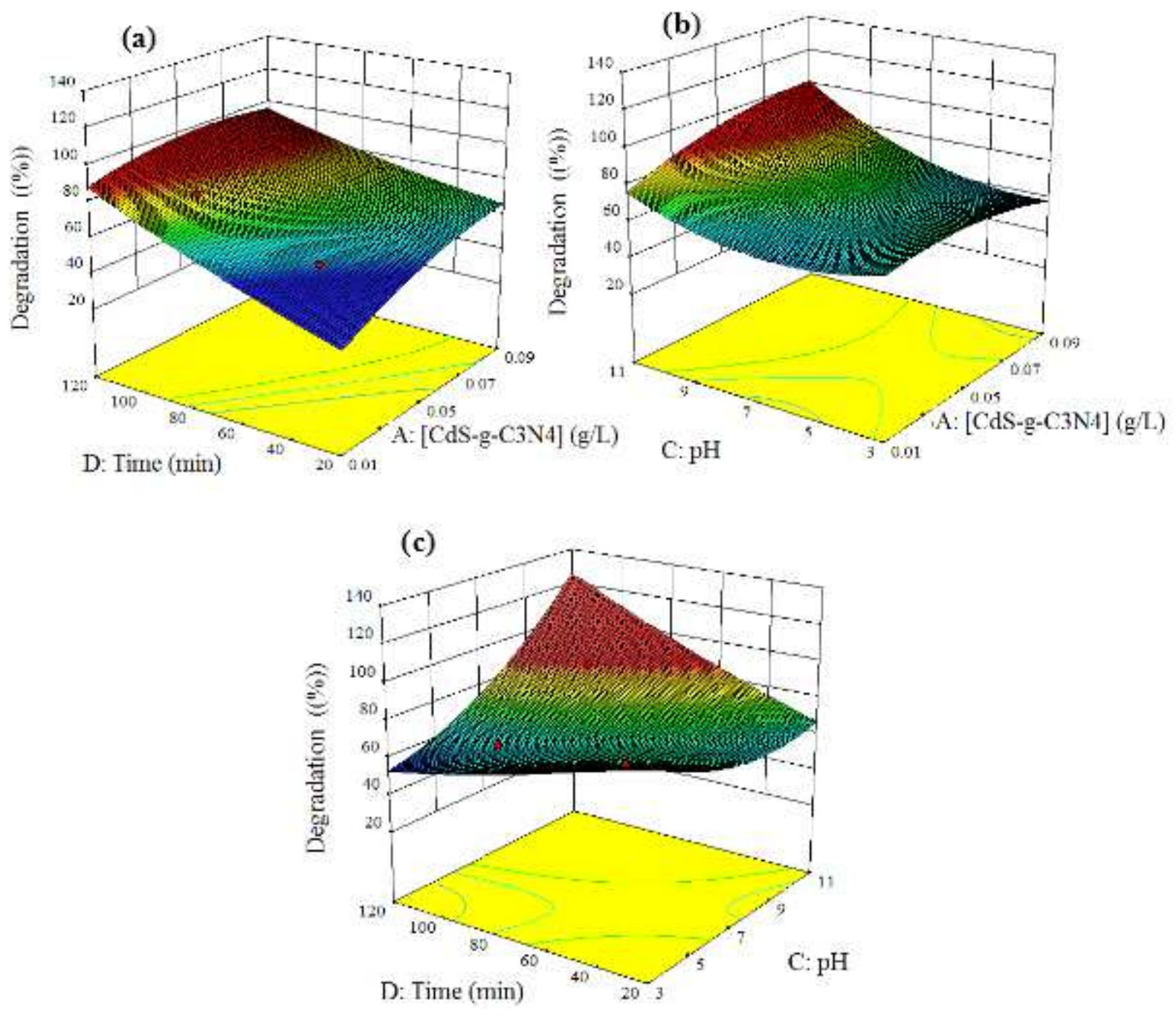

Figure 7

Response surface plots of the CTX photodegradation percentage as a function of (a) concentration of CdS-g-C3N4 nanocomposite and time (b) concentration of CdS-g-C3N4 nanocomposite and pH (c) time and $\mathrm{pH}$. 


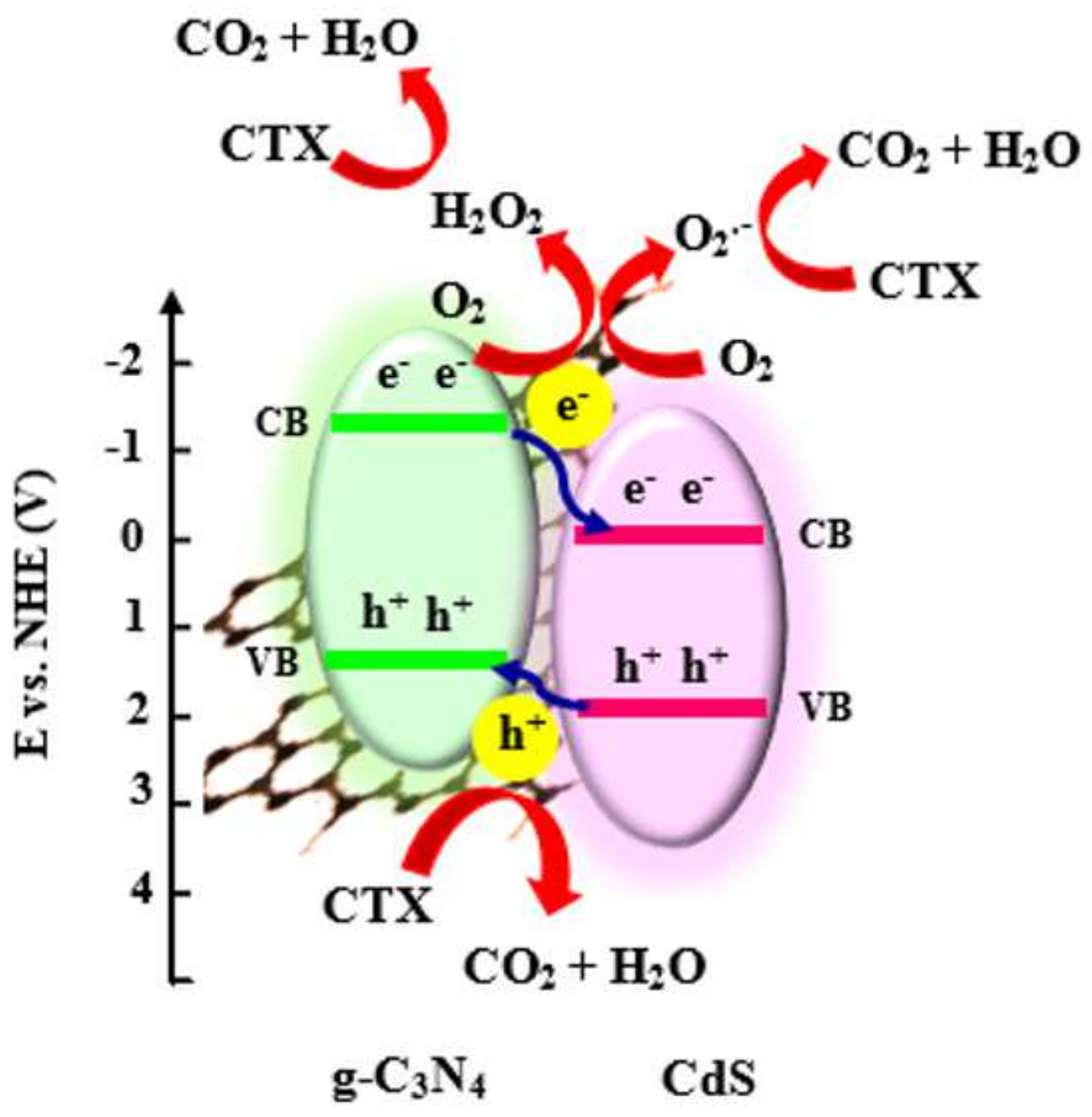

Figure 8

The schematic illustration of photodegradation mechanism for CTX decomposition using CdS-g-C3N4 photocatalyst under visible light. 


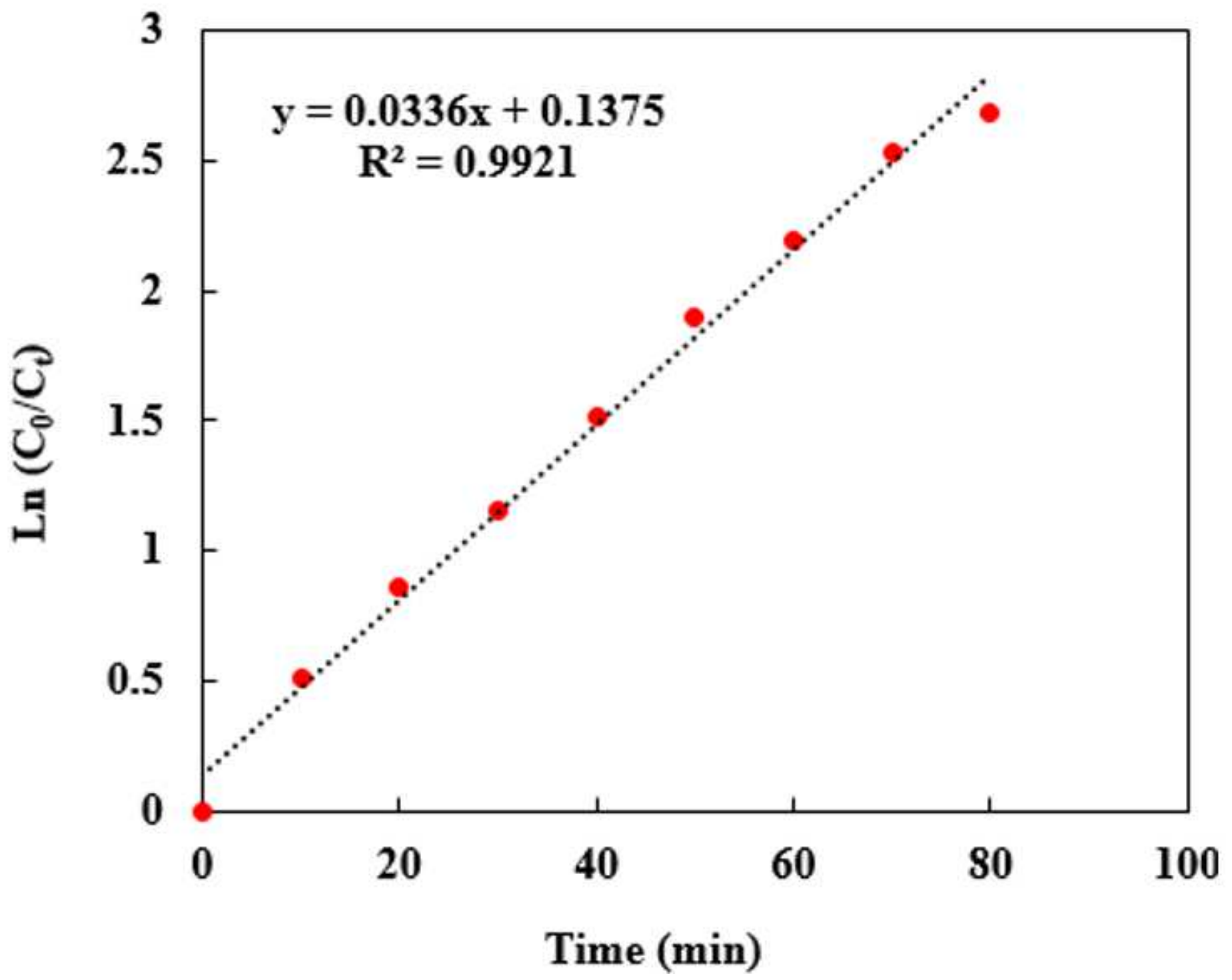

Figure 9

Please see the Manuscript Doc file for the complete figure caption. 